\title{
Right OF ReCourse Claims BASED ON LATENT DEFECTS IN THE NUCLEAR ENERGY SECTOR IN INDIA: BRACE YOURSELF FOR FACT-INTENSIVE DISPUTES
}

\author{
M P Ram Mohan ${ }^{\dagger}$ \& Els Reynaers ${ }^{\dagger \dagger}$
}

\begin{abstract}
This paper analyses how a case were to unfold if an operator of a nuclear installation were to exercise its right of recourse against a supplier in the event of supply of equipment or material with latent defects, as envisaged under the unique Section 17(b) of the Civil Liability for Nuclear Damage Act, 2010 (CLND Act), adopted by the Indian Parliament. This study is relevant as no such right of recourse claim has ever been exercised yet by a nuclear installation operator against a supplier, in the absence of any contractual agreement - and yet, this is precisely what this new law in India foresees as a perfectly valid legal option. The uniqueness of this provision and many grey areas surrounding this law have had a dampening effect on the global supplier market for nuclear power plants in India, other than for the indigenously designed Pressurised Heavy Water Reactors. This is why it is worth dissecting how such a case were to unfold, should the Indian nuclear power operator nevertheless decide to rely on this right of recourse provision. Unlike the relationship between claims filed by victims against the nuclear operator, the right of recourse claim by the operator against the supplier would be governed by standard tort law. We, therefore, evaluate general tort law principles as well as case law derived from comparable sectors, such as the oil and aviation industries, where any major accident is perceived as a lowprobability event, but with high impact on the society. In doing so, we will also scrutinise the meaning of "latent defects" as defined contractually, with the supplier's obligation to remedy the defect,

\footnotetext{
$\dagger$ M P Ram Mohan is an Associate Professor at Indian Institute of Management Ahmedabad; a Member of the Bureau of Indian Standards'-Nuclear Energy for Peaceful Applications Committee which formulates standards for nuclear energy usage in India; and serves as the President of Nuclear Law Association, India. <mprmohan@iima.ac.in>

i† Els Reynaers is a Partner at M V Kini Law Firm; Deputy Chair of the Environment, Health and Safety Law Committee of the International Bar Association; and serves as the General Secretary of Nuclear Law Association, India and Board Member of the
} International Nuclear Law Association.<els@mvkini.com>
\end{abstract}


versus the monetary damage claim from the operator against the supplier based on a latent defect after the occurrence of a nuclear incident. Hence, this paper is intended as a guide for all practitioners in the nuclear energy field, but it could also be of interest to experts in comparable sectors, or even large infrastructure projects.

I. INTRODUCTION-NUCLEAR LAW As A SPECIFIC SUbJeCt LAW DEVIATING FROM GENERAL TORT LAW ................................28

II. Right OF RECOURSE UnDER The VIENNA CONVENTION, PARIS CONVENTION AND CSC.

III. SECTION 17 OF THE CLND ACT: INSERTING A THIRD GROUND For Right OF RECOURSE FOR THE OPERATOR AND Related Parliamentary Debates.. 298

IV. Right OF RECOURSE OF OPERATOR AGAINST SUPPLIER UNDER SECTION 17(B) BASED ON TORT LAW 306

V. TORT LAW PRINCIPLES 307

VI. LATENT DEFECTS: StandARd CONTRACTUAL DEFECT LIABILITY PERIOD/ REMEDY BUT DisTINCT LIMITATION Periods For Section 17(B) Claims

A. Latent Defects And Latent Defects Liability Remedy As Contractually Defined. 310

B. Distinct Limitation Periods Applicable Between VictimOperator Claims (CLND Act) And Operator-Supplier Claims (Tort Law). 316

VII. CASE Law Relating To Latent DeFECTS.............................321

VIII. INDIA NUCLEAR INSURANCE POOL AND ITS JOINT RISK MANAGEMENT SYSTEM 332

IX. CONCLUSION. .336

\section{INTROdUCTION-NUCLEAR LAW AS A SPECIFIC SUbJECT LAW DEVIATING FROM GENERAL TORT LAW}

Before we delve into the key question underpinning this study and examine how a case were to unfold before a court, if an operator of nuclear installation in India were to exercise its right of recourse against a supplier in the event of supply of equipment or material with latent defects, as envisaged under the Civil Liability 
for Nuclear Damage Act, 2010 (CLND Act), ${ }^{1}$ it is worth reiterating some of the basic principles driving the specific civil liability regimes for nuclear damage internationally and how these have been applied specifically in India. ${ }^{2}$

Given the complexity of any litigation which might ensue after any major nuclear incident, potentially with transboundary dimensions, most countries have agreed from a policy perspective that general tort law may not be entirely well suited to the nuclear energy sector. This is mainly because a nuclear incident is inherently earmarked as a high-impact, low-probability event. This is true for other sectors such as the oil and aviation sector as well, where any major accident (with its low probability) will admittedly have a high impact on society. ${ }^{3}$ From a public policy perspective, governments have felt that it would impose an unjustified burden on the public and its victims to file civil liability claims based on tort law principles, with the requirement to establish negligence of the defendant(s) and ensuing lengthy litigation. This gave rise to one of the key nuclear liability principles: legal channelling of liability to

1 The Civil Liability for Nuclear Damage Act, No. 38 of 2010, INDIA CODE (2010), https://indiacode.nic.in/handle/123456789/2084?sam_handle=123456789/1362 (India) [https://perma.cc/K59B-N8MX] [hereinafter CLND Act]. The Civil Liability for Nuclear Damage Rules, 2011, Gazette of India (Nov. 11, 2011), http://prsindia.org/uploads/media/Nuclear\%20Rules/Civil\%20Liability\%20for\%20Nuclear \%20Damage\%20Rules\%202011.pdf [https://perma.cc/P5A2-KW2U] [hereinafter CLND Rules].

${ }^{2}$ Much has already been written about the Civil Liability for Nuclear Damage Act of 2010, the CLND Rules of 2011 and its possible interpretation, including, inter alia: See generally Robert J. Gruendel \& Els Reynaers Kini, Through the Looking Glass: Placing India's New Civil Liability Regime for Nuclear Damage in Context, 89 NuCLEAR LAW Bulletin 45 (2012) [hereinafter Through the Looking Glass]; Mohit Abraham, NuCleAR Liability: A Key Component of the Public Policy Decision to Deploy Nuclear ENERgy In Southeast Asia (American Academy of Arts and Sciences et al. eds., 2014); Els Reynaers Kini, India's NuClear Trade-InChing ForWARD?, Key DeVElopments in Environmental Law, Canada Law Book 101129 (Stanley Berger et al. eds, 2014); Els Reynaers Kini, News from the Front Lines of Nuclear Law, Proceedings of the Regional CONFERENCE 315330, (2015); M P Ram Mohan, Which Interpretational Route Will the Supreme Court of India Follow When Faced with the Contentious Civil Liability for Nuclear Damage Act, 2010?, 40 StatuTE L. Rev. 249, 24965 (2018), https://doi.org/10.1093/slr/hmy007 [https://perma.cc/AF85-P9WM]; M P Ram Mohan, Nuclear Liability Law in India. An Appraisal of Extent of Liability, Right of Recourse and Transboundary Application, 17 J. RISK RES. 1 (2013).

${ }^{3}$ Bernice Lee, Felix Preston \& Gemma Green, Preparing for High-impact, Lowprobability Events: Lessons from Eyjafjallajökull, A CHATHAM HOUSE REPORT (Jan. 2012), https://www.chathamhouse.org/sites/default/files/public/Research/Energy,\%20Environmen t\%20and\%20Development/r0112_highimpact.pdf [https://perma.cc/HG7D-G77M]. 
the operator according to which only the operator will be deemed to be exclusively liable for nuclear damage, a legal fiction created based on public policy in order to ensure the prompt compensation for victims by the operator and to avoid a legal imbroglio for the victims. This was also driven by pragmatic concerns of the insurance sector to ensure that only the operator would need to take out insurance and not all the other suppliers involved in the construction of a nuclear installation and thereby allows "a concentration of the insurance capacity available."4

Without going in further detail we merely want to flag that the U.S. - though historically a major supporter and influencer of the international conventions relating to civil liability for nuclear damage which contain limited right of recourse grounds against suppliers, to protect the interests of U.S. supplier companies engaged in the nuclear energy sector in other countries-opted domestically for a system based on economic channelling in its Price-Anderson Nuclear Industries Indemnity Act, 1957 (PriceAnderson Act), a system akin to legal channelling. ${ }^{5}$ Under this economic channelling model, the operator must take out an "omnibus coverage," encompassing his own third-party liability as well as that of the suppliers, but where the right of victims to sue the supplier directly has remained intact (in line with general tort law). It is also noteworthy that the rationale of the principle of legal towards the operator, which by and large excludes the liability of the suppliers, is increasingly being questioned by certain authors. ${ }^{6}$

Importantly, in domestic and international nuclear law, the operator of a nuclear installation will be held liable without a victim

${ }^{4}$ For a detailed analysis of the nuclear liability principles: INT'L ATOMIC ENERGY Agency, HandBook NuCleAr LAw 109-16 (2003) [hereinafter IAEA]; pertaining to Paris regime, see also Paris Convention on Nuclear Third Party Liability, NuClEAR ENERGY AGENCY, https://www.oecd-nea.org/law/paris-convention.html [https://perma.cc/WM5T3EG4].

5 The Price-Anderson Nuclear Industries Indemnity Act, Pub. L. No. 85-256, 71 Stat. 576 (1957).

${ }^{6}$ See generally Evelyne Ameye, Channelling of Nuclear Third Party Liability Towards the Operator: Is it Sustainable in a Developing Nuclear World or Is There a Need for Liability of Nuclear Architects and Engineers?, 19 EuR. ENERGY \& ENVTL. L. REV. 33 (2010); Evelyne M. Ameye, United States and India: Two Nuclear States with Legislation That Truly Holds Responsible Parties Liable in Case of a Nuclear Accident, 18 J. RISK RESEARCH 1070 (2014),

https://www.tandfonline.com/doi/abs/10.1080/13669877.2014.971421

[https://perma.cc/7C9H-GPG2]. 
establishing the negligence of the operator. This principle of strict liability is an important alleviation of the burden of proof otherwise resting on a plaintiff. As we will discuss below, this principle of strict or absolute liability governs the legal relationship between the operator and the victim, but not that of the operator vis-à-vis the supplier when the operator relies on his right of recourse, which is elaborately discussed in the later sections.

As is well-known, the Indian Supreme Court adopted the far-reaching environmental liability concept of absolute liability for enterprises engaged in hazardous or inherently dangerous activities. The enterprises will be held absolutely liable to compensate those affected by an accident (for instance, in the case of accidental leakage of a toxic gas) and such liability will not be subject to any of the exceptions (that is, act of God, act of third party, consent of victim and statutory authority) under the tort principle of strict liability in Rylands $v$ Fletcher. ${ }^{7}$ Hence, the notion of strict liability is not unique to the nuclear energy sector as such but can be found back in many jurisdictions when the civil liability of industries engaged in inherently hazardous activities is addressed, albeit with high-impact, low-probability type incidents related to these sectors.

Another nuclear law principle which in some way is a corollary or a trade-off of the unique legal channelling mechanism is that the liability of the operator will be limited both in amount as well as in time. Under the general tort law, there would not be such a capped liability amount for a defendant, and the only time limitation would be the one calculated as per the respective general laws of limitation applicable to tort laws, predefining the time within which any plaintiff would need to file its claim for damages. The limitation of liability in amount for the operator, necessarily implies that the State will step in and pay compensation to the victims in case the compensation amounts exceed the statutory determined liability amounts of the operator, an aspect which is often explicitly addressed in domestic laws, including in the CLND Act. $^{8}$

Other nuclear liability principles which one finds in the nuclear liability conventions are: the need for the operator to have an insurance or other financial security covering its specified

\footnotetext{
${ }^{7}$ M.C. Mehta v. Union of India, AIR 1987 SC 1086 (India).

${ }^{8}$ IAEA, supra note 4, at 113; see also CLND Act, supra note 1, at $§ 7$.
} 
liability amount at all times, which is often referred to as the congruence principle between liability and coverage; and which has also been embedded in the CLND Act. ${ }^{9}$

To further ensure smooth handling in case of claims by victims in the event of a nuclear incident, the nuclear liability conventions require that each country clearly ensures that only one court or body with the necessary authority will have jurisdiction over such cases. ${ }^{10}$ The CLND Act provides that the Claims Commissioner or the Nuclear Damage Claims Commission will be adjudicating such claims. ${ }^{11}$ Because many domestic laws pertaining to civil liability for nuclear damage may not necessarily address jurisdictional aspects in the event of a nuclear incident with transboundary ramifications (but to which their domestic private international law principles would apply), the nuclear conventions effectively harmonize this aspect by requiring that only courts of the State in which the nuclear incident occurs will, as a general rule, have jurisdiction. Moreover, these conventions mandate compliance with another nuclear law principle, to know, the nondiscrimination principle, whereby domestic laws and the civil liability for nuclear damage conventions must apply equally to all victims, regardless of their nationality, domicile or residence. ${ }^{12}$

Because of the unique characteristics of some of these nuclear law principles which deviate from general tort law in very significant aspects, these international conventions and domestic legislations such as the CLND Act, must be viewed as lex specialis (from the Latin saying: lex specialis derogat legi generali, i.e. a specific law derogating from the general law). Judges must take into account a rule of interpretation whereby the special law will prevail over the general law.

It is rather beyond doubt that the CLND Act fully incorporates the basic nuclear liability principles discussed above, to know: (1) legal channelling of liability towards the operator; (2) strict liability of the operator; (3) limitation of liability in amount; (4) limitation of liability in time; (5) congruence of liability and coverage; and (6) exclusive jurisdiction. However, as we will discuss in depth in the sections below: Section 17(b) of the CLND

${ }^{9}$ IAEA, supra note 4, at 114; see also CLND Act, supra note 1, at $\S 8$.

10 IAEA, supra note 4, at 115.

11 CLND Act, supra note 1, at pts. III \& V.

12 IAEA, supra note 4, at 115. 
Act expands the right of recourse ground of the operator against the supplier compared to the Paris and Vienna regimes beyond situations which the parties contractually agreed. It is precisely this open-ended nature of the right of recourse provision under the CLND Act beyond the scope of the operator-supplier contract, including, for instance, the contractual defect liability period, that has had a dampening effect on the potential suppliers and the global insurance industry to confidently enter the nuclear energy sector in India.

Public policy discussions pertaining to the soundness of excluding the nuclear energy sector from general tort law principles can be traced back to the 1950s before the adoption of the international conventions addressing civil liability for nuclear damage, which we will discuss further below. Some of these proand-contra views were echoed in the Parliamentary debates before the adoption of the CLND Act, which we will briefly touch upon as well.

\section{Right OF Recourse Under The Vienna ConVENTION, PARIS CONVENTION AND CSC}

As per Article X of the 1997 Vienna Convention, adopted under the IAEA regime: "the operator shall have a right of recourse only-(a) if this is expressly provided for by a contract in writing; or (b) if the nuclear incident results from an act or omission done with intent to cause damage, against the individual who has acted or omitted to act with such intent."13 It further states that the right of recourse provided for under this Article may also be extended to benefit the Installation State insofar as it has provided public funds pursuant to this Convention. ${ }^{14}$

Article 6(f) of the 1960 Paris Convention (as amended), adopted under the auspices of the OECD, according to which the operator shall have a right of recourse only: " $i$. if the damage caused

13 IAEA, Vienna Convention on Civil Liability for Nuclear Damage, IAEA Doc. INFCIRC/500 (Mar. 20, 1996) (adopted in 1963), amended by IAEA, Protocol to Amend the Vienna Convention on Civil Liability for Nuclear Damage, IAEA Doc. INFCIRC/566 (July 22, 1998) (entered into force in 2003), https://www.iaea.org/publications/documents/infcircs/protocol-amend-vienna-conventioncivil-liability-nuclear-damage [https://perma.cc/53MS-GRGP].

${ }^{14} I d$. 
by a nuclear incident results from an act or omission done with intent to cause damage, against the individual acting or omitting to act with such intent; ii. if and to the extent that it is so provided expressly by contract." 15

India is not a party to either the Paris or the Vienna regime, but it did ratify the Convention on Supplementary Compensation for Nuclear Damage, 1997 ("CSC") on 4 February 2016, which entered into force in 2015. ${ }^{16}$ The CSC is open not only to States that are parties to either the Vienna Convention on Civil Liability for Nuclear Damage or the Paris Convention on Third Party Liability in the Field of Nuclear Energy, but also to other States provided that their national legislation is consistent with uniform rules on civil liability laid down in the Annex to the Convention. ${ }^{17}$ Hence, India is an "Annex State" in the context of the CSC.

The right of recourse provision in the Annex to the CSC (Article 10), just like under the Vienna and Paris Conventions, foresees only two situations wherein the operator would have a right of recourse, to know:

National law may provide that the operator shall have a right of recourse only:

(a) If this is expressly provided for by a contract in writing; or

(b) If the nuclear incident results from an act or omission done with the intent to cause damage, against the individual who has acted or omitted to act with such intent. ${ }^{18}$

15 Paris Convention on Third Party Liability in the Field of Nuclear Energy (1960), in particular Article 6(f), as supplemented by the Brussels Supplementary Convention of 1963 (BSC), and revised by the Additional Protocol of 1964 and the Protocol of 1982, under the auspices of the OECD (note that the 2004 Protocols to amend the Paris Convention and the BSC are not yet in force), https://www.oecdnea.org/law/nlparis conv.html [https://perma.cc/4HKR-US4E] and https://www.oecdnea.org/law/paris-convention-protocol.html [https://perma.cc/WFQ9-WT6M].

${ }^{16}$ IAEA, Convention on Supplementary Compensation for Nuclear Damage, IAEA Doc. INFCIRC/567 (Jul. 22 1997), https://www.iaea.org/sites/default/files/infcirc567.pdf [https://perma.cc/T38N-P4MX].

17 IAEA, supra note 4.

18 IAEA, supra note 16 , at 38 . 
As we will further discuss in detail below, the CLND Act has quite uniquely inserted a third stand-alone ground, independent of any contractual agreement between the operator and the supplier with regard to the right of recourse, if the nuclear incident has resulted as a consequence of an act of supplier or his employee, which includes supply of equipment or material with patent or latent defects or sub-standard services.

McRae explains when reflecting upon the CSC negotiations, that not each CSC provision was intended to be equally mandatory, albeit that for "some provisions and definitions, however, it was determined that their treatment needed to be exactly the same in all member countries in order to support an effective and protective global regime. These provisions and definitions (relating primarily to compensation, jurisdiction, and the definition of nuclear damage) were included in the body of the CSC so that all member countries must comply with them." ${ }^{19}$ Conversely, for other provisions it was understood that there could be domestic variations and they would not need to be identical. ${ }^{20}$ Similarly, the IAEA's Explanatory Text to the CSC when touching upon the need to adopt national legislation clearly distinguishes the different clauses in the Annex, many of which cannot be treated as self-executing. More specifically, when referring to Article 10 of the CSC on the right of recourse, the chapeau states: "National law may provide that the operator shall have a right of recourse only: (.. )," which gives each Annex State "the faculty to complement, or derogate from the Annex's provisions; in these cases, it is for each Contracting Party, nuclear or non-nuclear, to decide whether or not it is its interest to exercise this faculty." 21

Upon ratification, the Indian Government submitted the following statement:

The Government of India, in accordance with paragraph 1 of Article XVIII of the Convention,

\footnotetext{
19 Ben McRae, The Convention on Supplementary Compensation for Nuclear Damage: Catalyst for a Global Nuclear Liability Regime, 1 NuClEAR L. Bull. 17, 24 (2007).

${ }^{20} I d$.

21 See Carlton Stoiber Et Al., Handbook On Nuclear Law (2003); International Atomic Energy Agency, The 1997 Vienna Convention on Civil Liability for Nuclear Damage and the 1997 Convention on Supplementary Compensation for Nuclear Damage-Explanatory Texts, 3 IAEA INT'L L. SERIES (2017).
} 
declares that its national law complies with the provisions of the Annex to the Convention; India has enacted the Civil Liability for Nuclear Damage Act of 2010 to provide for civil liability for nuclear damage and prompt compensation to the victims of a nuclear incident through a no-fault liability regime channelling liability to the operator, appointment of Claims Commissioner, establishment of Nuclear Damage Claims Commission and for matters connected therewith or incidental thereto. The Civil Liability for Nuclear Damage Act of 2010 complies with the provisions of the Annex to the Convention on Supplementary Compensation for Nuclear Damage. ${ }^{22}$

Importantly, the brief reference above to the right of recourse provisions in the Vienna Convention, Paris Convention, and CSC entails that such recourse by the operator against a supplier is very much acknowledged under both the Vienna and Paris regimes. However, in business practice, a right of recourse clause is typically not inserted in the operator-supplier contracts. On the contrary, exculpatory contract clauses or "hold harmless" clauses will typically be negotiated whereby the operator of a nuclear power plant will agree contractually to defend, indemnify and hold harmless the supplier against any loss, liability, damage, or claim, resulting from any recourse by any third party against the supplier, arising out of a nuclear incident in connection with their contracts. This further explains the unease with which the nuclear business community looks at the expansion of the right of recourse under the CLND Act.

Similarly, even bilateral agreements tend to exclude a right of recourse provision, thereby making such right of recourse clauses much less common than perhaps generally assumed. ${ }^{23}$

${ }^{22}$ IAEA, Convention on Supplementary Compensation for Nuclear Damage, (Feb. 4, 2016),

https://wwwlegacy.iaea.org/Publications/Documents/Conventions/supcomp_reserv.pdf [https://perma.cc/2U3D-NGZ8].

23 See e.g. Pre-Legislative Briefing Service (PLBS) (nOw: VIDHI), AdDEndum to A Briefing Document on the Civil Liability for Nuclear Damage Bill, 2010: Questions of Constitutionality and Legislative Options Open to Parliament 56 (2010), 
Perhaps this prevalent business practice in most jurisdictions not to insert right of recourse clauses in operator-supplier contracts should not come as such a surprise when one reviews the concerns and suggestion on how to avoid supplier liability from the business and insurance industry in the days before the adoption of the liability for nuclear damage conventions. Indeed, several insightful papers have analysed the historical origins of the limited right of recourse approach as part of the Harvard Report recommendations. ${ }^{24}$

The comprehensive Harvard Report, published in 1959, was undertaken as a joint collaboration between the nuclear industry and academia. ${ }^{25}$ In its Chapter on Private Arrangements to Limit Suppliers' Liability, it stated that:

[O]ne of the most widely discussed means by which a supplier may seek to protect himself against liability to third persons is the so-called 'holdharmless clause.' In its simplest form, this is an undertaking by the purchaser of the equipment, the licensee, or the operator of the atomic installation, by which he assumes the financial responsibility for any claims, of whatever nature and by whomever asserted, which may be established against the supplier on account of equipment or services furnished by the latter to the installation. This clause

https://vidhilegalpolicy.in/2011/11/18/PLBS_Addendum\%2520on\%2520Civil\%2520Nucle ar\%2520Liability\%2520Bill [https://perma.cc/U8TX-WEHL] [hereinafter PLBS ADDENDUM] (referring by way of example to Article III the France-Russian Federation Agreement (2000) and Article 1 of the Germany-Russian Federation Agreement (1998). See also Gopalan Balachandran, Should India Sign the Convention on Supplementary Compensation?, INST. FOR DEF. STUD. \& ANAlyses (Oct. 26, 2010), https://idsa.in/system/files/IB_IndiaCSV.pdf [https://perma.cc/JQ6G-RCEJ] (referring to Art. 13. of the India-Russia Intergovernmental Agreement which states that: "The Indian side and its authorized organization at any time and at all stages of the construction and operation of the Nuclear Power Plant (NPP) units to be constructed shall be the operator of the power units of the NPP and be fully responsible for any damage both within and outside the territory of the Republic of India caused to any person and property as a result of a nuclear incident during the transportation, handling or storage outside the NPPs of the nuclear fuel and contaminated materials or any part of NPP equipment both within and outside the territory of the Republic of India").

${ }^{24}$ Harvard Law School, International Problems of Financial Protection AgAinst NuClEAR RisK 95 (1959) [hereinafter HARVARD REPORT].

${ }^{25} I d$. 
seeks to put the purchaser or operator in the position of an insurer of the supplier's risk of liability. ${ }^{26}$

The Harvard Report further discusses some of the challenges and limitations (including in the absence of a legal/economic channelling regime) before concluding that "suppliers cannot adequately protect themselves against many of the risks of excessive liability inherent in atomic enterprises. Legislative or treaty action would seem to be called for." 27 The next Chapter of the Harvard Report then enumerates the areas where it believes Government action would be desirable, starting with the limitation of liability of the operator, while referring to similar approaches in the aviation and maritime sectors, but also supporting the principle that the operator's liability should be based on strict liability. ${ }^{28}$

The Harvard Report further addresses the need to limit the liability of suppliers as well, anticipating protracted litigation against operators and suppliers in the absence of a special regime as "[1]itigation for that purpose will nevertheless be harassing and its outcome might possibly be prejudiced by adverse public sentiment." 29 Therefore, the Harvard Report concludes

$[C]$ learly some corrective action is needed if the manufacturing industry is expected to participate fully in nuclear development. This does not necessarily mean that suppliers should be entirely exonerated from the consequences of any fault on their part. But the public should look, for recovery in tort, to the security fund established by the operator. Tort recovery outside that fund would result in a pyramiding of insurance costs, multiple recoveries, harassing and often fruitless litigation ....

It continued by explaining that if "the operator is required to carry compulsory insurance covering himself and his suppliers, then the question of who is formally liable loses much of its practical importance." ${ }^{\prime 3}$ This, of course, reflects the construction adopted

${ }^{26} I d$. at 42 .

27 Id. at 44 .

${ }^{28} I d$. at 45 .

${ }^{29} I d$. at 56.

${ }^{30} \mathrm{Id}$. at 57. 
under the US Price-Anderson Act, 1957, where victims can sue suppliers, but their liability is covered by the omnibus coverage of the nuclear operator. ${ }^{31}$ Hence, with regard to the section on exclusion of recourse actions in the Harvard Report, it states that "[w]here actions against suppliers are not excluded, the insurance industry would understandably prefer the Anderson-Price system, under which operators and suppliers are covered by the same insurance policy, for which the premiums are presumably paid by the operator." 32 And, as a practical matter, "recourse suits by the operator or by his insurers would, therefore, lack substance and would consist of mere bookkeeping operations of the insurer." 33 We may merely flag here that the "joint risk management" mechanism being proposed under the newly created India Nuclear Insurance Pool (INIP), which we will discuss in the last chapter of this Note, although very distinct from the Price-Anderson approach, is common to the Price-Anderson approach in that it ultimately seeks to move the potential operator-supplier right of recourse claims out of the realm of litigation before regular civil courts and into the field of a purely internal insurance settlement.

Most importantly, this 1959 Harvard Report concludes that the "retention of a right of recourse seems neither justified nor desirable, except perhaps in the extremely limited category of intentional damage." ${ }^{34}$ These US business concerns and positions as expressed in the Harvard Report, undoubtedly would have influenced the delegations in their discussions and negotiations of the 1963 Vienna Convention on Civil Liability for Nuclear Damage.

As Faure and Vanden Borre explain, both with regard to the 1960 Paris Convention and the 1963 Vienna Convention, the argument according to which the right of recourse by the nuclear operator ought to be curtailed was heavily influenced by the reasoning that otherwise each supplier would have to insure himself against the same risk already covered by the operator's insurance and "involve a costly duplication of insurance with no benefit to the

31 To read more about the US Price Anderson Act, see Michael G. Faure \& Tom Vanden Borre, Compensating Nuclear Damage: A Comparative Economic Analysis of the U.S. and International Liability Schemes, 33 William \& MARy Envtl L. \& POL'y ReV. 219 (2008)

${ }^{32}$ HARVARD REPORT, supra note 24 , at 57.

${ }^{33}$ HARVARD REPORT, supra note 24, at 57 n.20.

${ }^{34}$ HARVARD REPORT, supra note 24 , at 58. 
victims." 35 This is precisely the complaint raised by many in the international nuclear business and insurance sector against the unique insurance mechanism being proposed by INIP in India, as will be discussed below.

Turning back to the negotiations of the 1963 Vienna Convention, Faure and Vanden Borre discuss how an amendment was tabled with the proposal to allow the right of recourse by the operator against any person having manufactured materials or equipment or offered services in connection with the design, construction, repair or operation of the nuclear installation. ${ }^{36}$ Under this amendment, the operator would have a right of recourse against his supplier only if he proved the negligence of the supplier based on general rules of tort law. However, there was a lot of resistance against this amendment, warning that in such a case the "promotion of the atomic industry would be seriously jeopardised if the amendment were adopted." ${ }^{37}$ The proposed amendment was ultimately rejected (including by the US, UK, Canada, Germany, former USSR). ${ }^{38}$ Interestingly, the Official Records IAEA pertaining to the convention negotiations, indicate that India along with Argentina, Brazil and the UAE initially supported the insertion of this amendment, but that India ultimately did not vote in favour of it. ${ }^{39}$

Not unlike the discussions which took place in these international fora, the parliamentary debates of India's lower house shed a fascinating light on the underlying concerns pertaining to this right of recourse concept, as we will further discuss below.

Lastly, we may add that other Conventions pertaining to other sectors where the owner/operator may be held strictly liable and against which all civil liability claims will be channelled also acknowledge the right of recourse against third parties (although these sectors and related insurance mechanisms may be structured

\footnotetext{
35 Michael G. Faure and Tom Vanden Borre, Study on the Influence of Plant LifETIME EXTENSION (PLEX) ON NuCleAR LiABILITY 26 (2013) ,available at: https://secured-

static.greenpeace.org/france/PageFiles/300718/Study\%20\%20PLEX\%20nuclear\%20liabili ty.pdf [https://perma.cc/LXR6-VFLK] [hereinafter FAURE \& BORRE, PLEX STUDY] (referencing Exposé des Motifs, Motif 18, of the Paris Convention).

36 Id. at $26-27$.

${ }^{37} \mathrm{Id}$..

${ }^{38} \mathrm{Id}$.

39 PLBS ADDENDUM, supra note 23, at 5-6.
} 
differently); such as is the case with the civil liability for oil pollution damage ${ }^{40}$ or civil liability regarding the international carriage of persons, baggage, or cargo performed by aircrafts. ${ }^{41}$ In some of these conventions, however, the right of recourse provision of the owner/carrier is drafted in a much more open-ended manner, stated along the lines of "nothing in this Convention shall prejudice any right of recourse of the owner against third parties." 42 Thus, the right of recourse of the owner/operator in some of the conventions regulating similar low probability but high impact/liability exposure industries, is not limited to a few grounds.

\section{SECTION 17 OF THE CLND ACT: INSERTING A THIRD GROUND FOR RIGHT OF RECOURSE FOR THE OPERATOR ANd Related Parliamentary Debates}

Section 17 of the CLND Act states that [The] operator of the nuclear installation, after paying the compensation for nuclear damage in accordance with Section 6, shall have a right of recourse where-

(a) such right is expressly provided for in a contract in writing;

(b) the nuclear incident has resulted as a consequence of an act of supplier or his employee, which includes supply of equipment or material with patent or latent defects or sub-standard services;

40 United Nations, Liability And COMPEnSATION For Ship-Source Oil Pollution: An Overview of the International Legal Framework for Oil Pollution Damage FROM TANKERS 142-43 (2012)

41 The number of aviation conventions are many, and, hence, the reference to the 1999 Montreal Convention and its right of recourse provision is singled out as a specific illustration. See ICAO, Current Lists of Parties to Multilateral Air Law Treaties, https://www.icao.int/secretariat/legal/Lists/Current\%20lists\%20of\%20parties/AllItems.asp x [https://perma.cc/64ZL-VMGB].

${ }^{42}$ International Convention on Civil Liability for Oil Pollution Damage art 3, Nov. 27, 1992 , I.L.M.; Montreal Convention of 1999 art. 37, May 28, 1999 (demonstrating open-ended language of recourse in the context of air carrier liability); see also GIUSEPPE Contissa and Giovanni Sartor, Liabilities And Automation in Aviation 3 (2012) (explaining the possibility of recourse in the context of aviation). 
(c) the nuclear incident has resulted from an act of commission or omission of an individual done with the intent to cause nuclear damage.

As mentioned, Sections 17(a) and (c) of the CLND Act are standard provisions and can be compared directly with Article X of the Vienna Convention, Article 6(f) of the Paris Convention, and even Article 10 of the Annex to the CSC. Moreover, each of these international conventions restrict the right of recourse to the two instances outlined in Section 17(a) and 17(c) only. Therefore, the insertion of Section 17(b)-beyond the two "classic" ground of recourse grounds - has caused much international consternation.

Indeed, there are a few other domestic legislations which contain right of recourse provisions which slightly differ from the Paris and Vienna Conventions language but are similar in approach. For instance, the Republic of Korea in its 1969 Act on Compensation for Nuclear Damage (as amended in 2001) states in its Article 4 on the Right of Recourse:

(1) Where nuclear damage is caused by the wilful act or gross negligence of a third party, a nuclear operator who has provided compensation for nuclear damage in accordance with Article 3, shall have a right of recourse against such third party, provided however, that where the nuclear damage occurs due to the supply of material or services (including labour) for the operation of a nuclear reactor (hereinafter referred to as 'supply of material'), the nuclear operator shall have a right of recourse only insofar as there has been a wilful act or gross negligence by the supplier of the materials concerned or by his employees.

(2) If, in the circumstanced described in paragraph 1 of this Article, a special agreement has been made regarding rights of recourse, such agreement shall govern. ${ }^{43}$

\footnotetext{
${ }^{43}$ Nuclear Safety Act, Act No. 10911, July 25, 2011 (S. Kor.).
} 
The original Civil Liability for Nuclear Damage Bill, 2010, contained a differently worded Section 17(b), targeting the situation in which "the nuclear incident has resulted from the wilful act or gross negligence on the part of the supplier of the material, equipment or services, or of his employee," much like the law of the Republic of Korea just quoted. However, during deliberations before the Parliamentary Standing Committee, various experts expressed the view that this provision needed to be redrafted in line with provisions from product liability laws with a lower evidentiary threshold compared to the situations of gross negligence that hold the supplier liable for product liability, faulty design, faulty manufacture, etc. ${ }^{44}$ The Parliamentary Standing Committee shared the view of the experts according to which it would be impossible to establish the "willful act or gross negligence" on the part of the supplier ${ }^{45}$ and that therefore, "there should be a clear cut liability on the supplier of nuclear equipment/material in case they are found to be defective." 46

As a result, the Parliamentary Committee suggested that Clause 17(a) and 17(b) be connected with the word "and." This proposal was ultimately not upheld by Parliament in the final version of the CLND Act, but it clarifies that initially the intent was to hyphen both sections, and that the right of recourse grounds as foreseen in Section 17(b) would only apply if there was also a contractual right of recourse clause agreed between the operator and the supplier; and not in the absence of it. ${ }^{47}$ In other words: the Committee did not envisage that Section 17(b) would become a stand-alone clause, independent of an explicit contractual right of recourse clause. This is further borne out by the Committee's statement according to which the operator "may, after, compensating the victims, exercise his right of recourse against the

\footnotetext{
${ }^{44}$ Robert J. Gruendel \& Els Reynaers Kini, Through the Looking Glass: Placing India's New Civil Liability Regime for Nuclear Damage in Context, NuCLEAR LAW Bulletin, No. 89, 49-50 (2012). Els Reynaers Kini, CANada LaW Book (Stanley Berger et al. eds, 2014). For original sources, see DEPARTMENT-RELATED PARLIAMENTARY Standing Committee on Science \& Technology, Environment \& Forests, $212^{\text {Th }}$ Report on The Civil Liability for Nuclear Damage Bill 5 (2010) [hereinafter Report PARLIAMENTARY STANDING COMMITTEE].

45 RePort PARliamentary Standing COMmittee, supra note 44, at 16.

${ }^{46} I d$.

47 RePort PARLiamentary StANDING COMmitTEe, supra note 44.
} 
supplier in accordance with the provisions of the contract."48 Therefore, the Committee assumed that such an explicit contractual right of recourse provision would be a standard clause in operatorsupplier contracts; whereas, as we have mentioned above, this is generally not the case in supplier contracts in the nuclear energy sector. Quite the contrary: hold harmless clauses by the operator in favour of the supplier are the norm globally, not right of recourse clauses.

The Parliamentary Standing Committee ultimately recommended that Section 17(b) should be modified as: "the nuclear incident has resulted as a consequence of latent or patent defect, supply of subs-standard material, defective equipment or service, or from the gross negligence on the part of the supplier of the material, equipment or services." 49 In short, in this version the product liability language was placed in addition to the eventuality of "gross negligence."

Importantly, the revised language Section 17(b) in the CLND Bill presented to Parliament did not contain the connecting term "and" between Section 17(a) and (b), but instead read as "the nuclear incident has resulted as a consequence of an act or supplier or his employees, done with the intent to cause nuclear damage, and such act includes supply of equipment or material with patent or latent defects or sub-standard services; ....",50

In Parliament, one found a lot of criticism on the initial recommendation by the Parliamentary Committee to connect Section 17(a) and (b) - which was anyway not retained in the revised version of the Bill presented to Parliament, as well as on the new inclusion of the "intent" element in the final version of the Bill. $^{51}$ If one were to summarise the observations from various

\footnotetext{
48 Report Parliamentary Standing Committee, supra note 44, at 16.

49 Id.

${ }^{50}$ Italics added to emphasize the portion which was not retained in the final CLND Act.

51 Lok Sabha Debates, Fifteenth Series, Vol. XiI, Fifth Session, 2010/1932 (SAKa) No. 22, Wednesday, August 25, 2010/ Bhadra 3, 1932 (SAKA) (2010) (inter alia: "When the original Clause was amended further and when there was a suggestion in the Standing Committee for strengthening Clause 17, what the Government did surreptitiously was that they added one word 'and', and this particular word 'and' changed the entire meaning of that Clause. When there was hue and cry, uproar outside Parliament, then the Government removed the word 'and' and put another word 'intent' which further weakened that Clause. If that word 'intent' remains in the Clause, how can anybody prove the intent of the supplier?").
} 
parties regarding Section 17(b), it would be that the government should not absolve the supplier from liability, and, consequently, the "intent" qualification was vehemently opposed by most as it "substantially nullifies the supplier's responsibility." 52

Other suggestions put forward to the Parliamentary Committee reviewing the Original Bill, consisted of enlarging the right of recourse in terms of the actors who could rely on such a recourse. ${ }^{53}$ Given that India has adopted a capped liability structure for the operator ${ }^{54}$ with the remaining compensation amount to be paid to the victims to be provided for by the Central Government, it was proposed that the Central Government should also be entitled to rely on this right of recourse provision against the supplier for the differential amount. ${ }^{55}$ As observed by the authors previously, it "does tend to show that in fact a rather innovative review of the notion of recourse against the supplier itself took place during the public debate phase of the CLND Act." ${ }^{56}$

Most parliamentarians were made aware that there were only few countries with an extended right of recourse provision and that this could impede their accession to standard third party civil liability agreements, in particular the CSC, which the Government may want to join at some point. However, the joining of the CSC was not seen as a priority by Parliamentarians at the time, and many felt India could not be rushed or bullied into doing so. In short, it was felt that the compatibility of the CLND Act and the CSC would be dealt with if and when India would need to cross that bridge. Some went as far as stating that it ultimately was a "buyer's market," and India should have the courage to dictate its terms. ${ }^{57}$ Only some lone voices expressed a concern that the law should not be made so stringent as to scare away investors altogether, ${ }^{58}$ but that possibility didn't seem to carry the weight it now does.

If the above discussions were not controversial enough, perhaps it is worth noting by way of historical addendum that

52 Canada Law BooK, supra note 44, at 117-118.

53 See PLBS ADDENDUM, supra note 23, at 16.

54 Article 6(2) of the CLND Act, according to which "the liability of an operator for each nuclear incident shall be (a) in respect of nuclear reactors having thermal power equal to or above ten MW Rupees one thousand five hundred Crores."

55 CLND Act, supra note 1, at art. 7.

56 CANADA LAW BOOK, supra note 44, at 118.

57 LoK SABHA DeBATES, supra note 51.

${ }^{58} I d$. 
several parliamentarians discussed the possibility of adopting an unlimited liability regime or placing the liability amount at a much more significant level. Nevertheless, the proposed amendment to place the liability amount as high as Rs. 10,000 Crores (USD 1.65 billion) was ultimately voted against by a vast majority. ${ }^{59}$

In light of the above parliamentary debates which went at great length in defining the precise contours of the right of recourse provision, courts when faced with an interpretation of Section 17(b) and relying on "external aids" would necessarily need to conclude that Parliament in the end wanted to both expand and disconnect Section 17(b) from the existence of any contractually agreed right of recourse provision. That is, courts would need to apply it, even if the parties had decided not to insert a contractual right of recourse clause as per Section 17(a). ${ }^{60}$

Quite clearly, the discussions pertaining to the operator's right of recourse did not take the existing Paris or Vienna regimes on civil liability for nuclear damage as a starting point. Rather, the Report of the Parliamentary Standing Committee states that it "has been the unanimous opinion of the Committee that the Bill being a domestic legislation should reflect Indian interests." $" 61$

We must add that the subsequent CLND Rules tried to reduce the scope of the right of recourse somewhat by specifying in Rule 24(1) that with regard to the contract referred to in clause Section 17(a) of the Act, such contract shall include a provision for right of recourse for not less than the extent of the operator's liability under Section 6(2) or the value of the contract itself, "whichever is less." 62 Rule 24(2) of the CLND Rules further specifies that the provision for the right of recourse referred to in Rule 24(1) shall be for the duration of the initial license issued under the Atomic Energy (Radiation Protection Rules), 2004 (which is five years), or the product liability period, "whichever is longer." 63 The "product liability period" is defined in Rule 24 as "the period for which the supplier has undertaken liability for patent

${ }^{59} \mathrm{Id}$. (merely 25 representatives voted in favour and 252 voted against this proposed amendment).

${ }^{60}$ KINI, INDIA's NuClEAR TRADE, supra note 2, at 119.

61 RePORT PARLIAMENTARy StANDing COMmitTeE, supra note 44, at 13.

${ }^{62}$ Gruendel \& Kini, Through the LoOKING Glass, supra note 2, at 51.

63 CLND Rules, supra note 1. 
or latent defects or sub-standards services under a contract."64 Hence, this now does clearly allow suppliers to limit their exposure to a period of five years. Rule 24 of the CLND Rules, with its sole reference to Section 17(a) of the CLND Act, where a right of recourse provision is expressly provided in a contract, clearly implies that for the two other situations covered under Section 17 of the CLND Act, there would be no such five-year time limit on the operator's right of recourse.

In other words: now that Section 17(a) and Section 17(b) of the CLND Act are not connected with the word "and", due to which Section 17(b) must be treated as a stand-alone provision independent of a contractual right of recourse clause, the operator can exercise a right of recourse if a supply of equipment or material with patent defects, latent defects, or sub-standard services has been provided, thereby considerably broadening the scope of the right of recourse of the operator under the law in India. ${ }^{65}$

As we have seen, a significant part of the Parliamentary debates and expert submissions were devoted to adapting the notion of the right of recourse of the operator against the supplier to the Indian context and not merely to accept the standard language used in treaties. While it was noted that expanding the right of recourse provision may not be in line with what is generally prescribed in international treaties on civil liability for nuclear damage, the more persuasive common ground across party lines was that an operator should effectively be placed in a position to sue a supplier if it could be established that he would have supplied sub-par equipment or services. ${ }^{66}$

Some of this debate is reminiscent of the original discussions which took place before the adoption of the Vienna Convention in 1963 , in which India took part and initially supported a version of the right of recourse provision where the operator could exercise the

\footnotetext{
${ }^{64}$ Rule 24(2)(b) further contains an "explanation" of the term "supplier" which "shall include a person who-

(i)Manufactures and supplies, either directly or through an agent, a system, equipment or component or builds a structure on the basis of functional specification; or (ii)Provides build to print or detailed design specifications to a vendor for manufacturing a system, equipment or component or building a structure and is responsible to the operator for design and quality assurance; or

(iii)Provides quality assurance or design services.” CLND Rules, supra note 1.

${ }^{65}$ Gruendel \& Kini, Through the LoOKING Glass, supra note 2, at 51.

${ }^{66}$ KINI, INDIA's NuCLEAR TRADE, supra note 2, at 119-121.
} 
right of recourse "against any person who has manufactured materials or equipment for, or who has furnished materials, equipment or services in connection with the design, construction, repair or operator of a nuclear installation, or who has transported or stored nuclear material, for fault of such person". ${ }^{67}$ As is known, this version didn't see the light of day, and other concerns, particularly pertaining to the spiraling cost and multiplication of insurance premiums, were more persuasive at that time. ${ }^{68}$ Remarkably, these financial implications for the suppliers or the nuclear sector more generally merely formed a vague background in the Indian parliamentary debates, and not a single elected representative defended this economic point of view, and, thus, was almost entirely ignored. This is in stark contrast with the focus of the Harvard Report which was adopted in 1959 and has since cast such a persuasive shadow on international nuclear civil liability law. ${ }^{69}$ The Harvard Report in its foreword admitted that it "inevitably reflects its American origin by its emphasis upon the special problems of the US supplier ...."70 The discussions in the Indian Parliament, almost 65 years after the publication of the Harvard Report, clearly placed the public interest on the forefront and arrived at an entirely different outcome in terms of the burden to be shouldered by a supplier in the nuclear sector. ${ }^{71}$

In fact, the more direct implications of Section 17(b) for the suppliers were never really analyzed, and many may not have fully grasped that in fact suppliers worldwide have never had to take out an insurance for their services/deliveries to a nuclear operator. Indeed, as has been highlighted by several authors, industry reality indicates that a contractual right of recourse clause is never inserted in the contractual arrangement between a nuclear operator and its

67 PLBS ADDENDUM, supra note 23, at 5-6.

${ }^{68}$ Id. For further analysis, see FAURE \& Borre, PLEX STUDY, supra note 35, at $9 \uparrow$ 70-73; and AMEYE, supra note 6.

69 PLBS ADDENDUM, supra note 23, at 5-6.

70 The foreword further states: "Moreover, we believe that the examination of the subject as it appears to the US supplier in the light of American law will be of value in other nations which will be dealing with US suppliers in coming years."

71 See, e.g. LoK SABHA Debates, supra note 51 (Mr. Prithviraj Chavan presenting the CLND Act: "I would like to take this opportunity to clarify one thing. While the limits of compensation are primarily for taking insurance, you cannot have insurance with no limits, but the compensation is, in fact, unlimited. I want the House to note this fact, whatever the compensation the Commissioner or the Commission will set, that compensation will be paid.") 
suppliers; bilateral agreements between countries exclude such a possibility or other dynamics drive this reality. ${ }^{72}$

This raises the more poignant question whether the right of recourse concept itself attracts sufficient review in international fora regarding its true function, aim, utility, and ultimately underlying policy. Whether or not one agrees with its implications, the Indian parliamentary debates have the advantage of at least having given the right of recourse notion a contemporary review, based on the assumption that the Indian operator would very often not have the contractual upper hand when negotiating this particular clause with a supplier. ${ }^{73}$

\section{Right OF RECOURSE OF OPERATOR AGAINST SUPPLIER UNDER SECTION 17(B) BASED ON TORT LAW}

There are a couple of key elements that must be culled out from Section 17(b) CLND Act, according to which the "operator of the nuclear installation, after paying the compensation for nuclear damage in accordance with Section 6, shall have a right of recourse where ... the nuclear incident has resulted as a consequence of an act of supplier or his employee, which includes supply of equipment or material with patent or latent defects or sub-standard services." ${ }^{, 74}$

We stated from the outset that nuclear law is a lex specialis carved out from standard tort law (see discussion above), precisely because it focuses on speedy compensation for victims and seeks to avoid year-long litigation where victims have to prove the fault of the operator or any of its suppliers. However, as much as the strict liability of the operator and the channelling of the liability towards the operator deviates from standard tort law principles, the same cannot be said about the right of recourse provision where the operator will have to establish and prove the applicability of the situations covered under Section 17(b) before it can claim back the full or partial amount it paid to the victims based on the Award issued by the Claims Commissioner/Nuclear Damage Claims

72 PLBS AdDENDUM, supra note 23, at 13; AMEYe, supra note 6 (the author conducted a detailed study by sending questionnaires to about 50 operators and 50 designers/constructors worldwide to collate their views on liability allocations in the nuclear sector).

73 KINI, INDIA's NuClEAR TRADE, supra note 2, at 121.

74 CLND Rules, supra note 1. 
Commission. In other words: whereas the victims do not have to establish fault of the operator, the operator will have to establish fault of the supplier which possibly either supplied equipment or material with patent or latent defects or sub-standard services to successfully rely on its right of recourse.

It must be noted here that the phrasing of Section 17(b) is such that it states "which includes" supply of equipment or material with patent or latent defects, or sub-standard services, and hence, is not limited to those situations. This also implies if the contributory fault of the supplier in causing the nuclear incident can be established, Section 17(b) CLND Act can also be relied upon by the operator to claim back some or all of the money paid to the victims.

It is also worth mentioning that whereas Section 17(c) explicitly refers to both the act of commission or omission, Section 17(b) states that "the nuclear incident has resulted as a consequence or an act of supplier or his employee" seemingly excludes omissions which can't quite be the case given that under general tort law principles the notion of an "act" of a liable party will cover both acts and omissions, as will be further discussed below.

\section{TORT LAW PRINCIPLES}

The principal aim of tort law is compensation of victims or their dependants. The general principle of award of damages is, therefore, compensatory in nature. At times, however, exemplary damages can be imposed, and in that case the aim is more for deterrence of wrong-doers. ${ }^{75}$

An action for breach of contract necessitates privity between the parties to it, whereas in tort no such privity is needed. Importantly, the same act may amount to a tort as well as a breach of contract. Hence, once it is established that there was a latent defect (which then subsequently contributed to the nuclear incident), this factual proof may both entail a breach of contract as well as a tort, although the consequences attached to each would differ. As we have discussed above, the operator-supplier contracts in India do not contain clauses pertaining to liability in the event of a nuclear incident.

\footnotetext{
75 AKShay SAPre, The LAw Of TORTS 885 (LexisNexis 28th ed., 2018).
} 
Indeed, before the adoption of the CLND Act and in the international practice of the nuclear field, the operator in India inserted standard clauses on "Indemnity Against Loss/Damage" in its contracts with suppliers, which stated that: "the Purchaser shall indemnify and hold harmless the Contractor in respect of Third Party life and Property damage claims arising out of nuclear event at Purchaser's Site." However, after the adoption of the CLND Act, operator-supplier contracts no longer contain such hold harmless clauses. Such hold harmless clauses are, of course, very significant otherwise as it is well-established that a liability in tort will not be admitted if its effect would be to permit the plaintiff to circumvent or escape a contractual exclusion or limitation of liability. ${ }^{76}$

It is good to keep the basic elements of tort law in mind as we progress in our analysis. As is known, an act which infringes a legal right is a wrongful act, but every wrongful act is not a tort. To constitute a tort or civil injury the following elements must be present: 1) A wrongful act must be committed by a person; 2) The wrongful act must give rise to a legal damage or actual damage; and 3) The wrongful act must be of such a nature as to give rise to a legal remedy in the form of an action for damages. ${ }^{77}$ The crucial test of a legally wrongful act is its prejudicial effect on the legal right of another. Keep in mind that under the law of torts, the notion of "wrongful act" is used in a wide sense and includes both acts and omissions. Importantly, to every right there corresponds an obligation or duty. The duty with which the law of torts is concerned is the duty to abstain from causing an injury, to respect the property of others, and to use due diligence to avoid causing harm to others. ${ }^{78}$

There are different types of torts, including trespass, nuisance and negligence, which have each led to separate streams of case law over the years. Negligence is the breach of a duty caused by the omission to do something which a reasonable man, guided by those considerations which ordinarily regulate the conduct of human affairs would do; or doing something which a prudent and reasonable man would not do. ${ }^{79}$ It is well-established that there are three constituent elements of negligence, which the plaintiff must

\footnotetext{
76 Id. at 9.

$77 \mathrm{Id}$. at 13.

${ }^{78} \mathrm{Id}$. at 25.

79 Id. at 462.
} 
prove: (1) A legal duty to exercise due care (by the defendant towards the plaintiff); (2) breach of the said duty (by the defendant); and (3) consequential damage (suffered by the plaintiff). ${ }^{80}$ The test for deciding whether the defendant breached his duty is that of a reasonable or prudent man; albeit that this is a very contextual benchmark, where the particular sector and level of expertise of the defendant will be taken into account. Indeed, the question to be asked with regard a person's conducts is whether a prudent or careful or diligent man of his calling or business or expertise or skill would have undertaken the thing in question. In other words: if a person holds himself out as being specially competent to do things requiring professional skill, he will be held liable for negligence if he fails to exhibit the care and skill of an expert in that business. ${ }^{81}$

Another important difference between tort law and contract law is that many construction contracts contain clauses pertaining to liquidated damages, which provide a pre-determined ceiling in order to quantify damages which arise due to a breach of contract. Conversely, unliquidated damages are damages that are payable for a breach, the exact amount of which has not been pre-agreed. Importantly, when there is a pre-determined amount, there is no need to lead evidence to prove such damages unless the Court arrives at a conclusion that no damages are likely to arise from such breach. ${ }^{82}$ Indeed, in ONGC Ltd. v. Saw Pipes Ltd., the Supreme Court of India held that:

"... it can be held that when a contract has been broken, the party who suffers by such breach is entitled to receive compensation for any loss which naturally arises in the usual course of things from such breach. These sections further contemplate that if parties knew when they made the contract that a particular loss is likely to result from such breach, they can agree for payment of such compensation. In such a case, there may not be any necessity of leading evidence for proving damages, unless the

\footnotetext{
${ }^{80} I d$.

81 Id. at $485-487$.

82 See ONGC Ltd. v. Saw Pipes Ltd., (2003) 5 SCC 705 (India) (referring to the lengthy interpretation of Liquidated Damages and case law in this Judgment by the Supreme Court of India).
} 
Court arrives at the conclusion that no loss is likely to occur because of such breach. Further, in case where the Court arrives at the conclusion that the term contemplating damages is by way of penalty, the Court may grant reasonable compensation not exceeding the amount so named in the contract on proof of damages. However, when the terms of the contract are clear and unambiguous then its meaning is to be gathered only from the words used therein. In a case where the agreement is executed by experts in the field, it would be difficult to hold that the intention of the parties was different from the language used therein. In such a case, it is for the party who contends that stipulated amount is not reasonable compensation, to prove the same." 83

\section{LATENT DEFECTS: STANDARD CONTRACTUAL DEFECT LiABILITY PERIOd/ REMEDY BUT DisTINCT LiMITATION Periods For SeCtion 17(B) Claims}

\section{A. $\quad$ Latent Defects And Latent Defects Liability Remedy As Contractually Defined}

Before we turn to the case law relating to the interpretation of "latent defects" it is important that we understand the typical meaning given to it in the context of contracts between the operator and supplier (Purchaser-Contractor).

We will subsequently have to keep in mind different scenarios and timelines attached to these terminologies, as foreseen under contract and how it could be applied and interpreted to the stand-alone Clause 17(b) CLND Act with its clear intent given by Parliament to apply even independent of any contractual right of recourse provision.

Here's an overview in the Table below of key definitions typically inserted in supply of plant and equipment contracts in the

${ }^{83} I d$. 
nuclear energy field in India, much in line with international practice pertaining to infrastructure contracts: ${ }^{84}$

\begin{tabular}{|c|c|}
\hline Term & Definition \\
\hline Latent Defect & $\begin{array}{l}\text { Shall mean a defect, inherently lying within the material or arising out } \\
\text { of design deficiency, which do not manifest themselves and/or was not } \\
\text { reasonably discoverable during the Defect Liability Period. }\end{array}$ \\
\hline $\begin{array}{l}\text { Contractor's } \\
\text { General } \\
\text { Obligation(remedy } \\
\text { latent defects) }\end{array}$ & $\begin{array}{l}\text { The Contractor shall design (to the extent specified in the Contract), } \\
\text { procure/ manufacture (including associated Purchases and/or sub- } \\
\text { contracting), install and complete the Facilities with due care and } \\
\text { diligence in accordance with the Contract and with the Purchaser's } \\
\text { instructions, and shall remedy any defects in the Facilities occurring in } \\
\text { Defect Liability Period, and remedy latent defects within a further } \\
\text { period of five (5) years from end of the Defect Liability Period. }\end{array}$ \\
\hline Defect Liability & $\begin{array}{l}\text { The Contractor shall warrant that the Stores, Plant \& Equipment } \\
\text { supplied under the Contract shall be brand new, free from defects, } \\
\text { manufactured with the latest state-of-art of manufacture and conform } \\
\text { strictly in accordance with the technical specifications, drawings and } \\
\text { data sheets of the Contract. No deviation from these specifications or } \\
\text { alteration shall be made without specific and written accord of the } \\
\text { Purchaser. All Stores shall be guaranteed to be of the best quality of } \\
\text { their respective kinds and shall be free from defects in the design } \\
\text { engineering, materials, workmanship, and be of specified size and } \\
\text { capacity so as to fulfil in all respects the requirements of the Purchaser } \\
\text { as specified in the Contract. }\end{array}$ \\
\hline $\begin{array}{l}\text { Defect Liability } \\
\text { Period }\end{array}$ & $\begin{array}{l}\text { a) Items/Equipment/System } \\
\text { Defect Liability Period shall be } 18 \text { months from the date of completion } \\
\text { of facilities (satisfactory erection and pre-commissioning) or } 12 \text { months } \\
\text { from the date of Operational Acceptance of Facilities (Commissioning), } \\
\text { whichever occurs first, for each reactor unit. } \\
\text { In the event, the scope of work is limited to erection and pre- } \\
\text { commissioning of the facilities and commissioning will be done by the }\end{array}$ \\
\hline
\end{tabular}

${ }^{84}$ Note: these standard definitions have been copied from standard General Conditions of Contract for Supply of Indigenous Stores, NPCIL, as used even after the adoption of the CLND Act. 


\begin{tabular}{|l|l|}
\hline & $\begin{array}{l}\text { Purchaser, then the Defect Liability Period shall be 18 months from the } \\
\text { date of completion of facilities (satisfactory erection and pre- } \\
\text { commissioning) and handing over of the facilities for commissioning to } \\
\text { the Purchaser or 12 months form the date of commissioning of the } \\
\text { facilities, whichever occurs first, for each reactor unit. } \\
\text { b)Spares/Tools/Tackles/Accessories } \\
\text { The Defect Liability Period shall be } 18 \text { months from the date of receipt } \\
\text { of items (last consignment) at site or 12 months from the date of } \\
\text { acceptance, whichever occurs first. }\end{array}$ \\
\hline $\begin{array}{l}\text { Extension } \\
\text { Defects Leriod }\end{array} \quad \begin{array}{l}\text { o) If the Facilities or any part thereof cannot be used by reason of such } \\
\text { defect and/or making good of such defect, the Defect Liability Period of } \\
\text { the Facilities or such part, as the case may be, shall be extended by a } \\
\text { period equal to the period during which the Facilities or such part } \\
\text { cannot be used by the Purchaser because of any of the aforesaid reasons. } \\
\text { Upon correction of the defects in the Facilities or any part thereof by } \\
\text { repair/replacement, such repair/replacement shall have the Defects } \\
\text { Liability Period for a period of twelve (12) months from the time such } \\
\text { repair/replacement of the Facilities or any part thereof has been } \\
\text { completed. } \\
\text { b) In addition, the Contractor shall also provide an extended warranty } \\
\text { for any such component of the Facilities and during the period of time } \\
\text { as may be specified in the SCC. Such obligation shall be in addition to } \\
\text { the Defect Liability Period. }\end{array}$ \\
\hline Latent \\
Liability
\end{tabular}

It may be observed that the above clauses and approach are in line with the standard clauses suggested by some infrastructure contract committees who prepare standard templates for ease of doing business, such as the South African Joint Building Contracts Committee (JBCC) of South Africa, where Clause 22.1 addresses latent defects and states that "the latent defects liability period for the Works shall commence at the start of the construction period 
and end 5 years from the certified date of final completion." ${ }^{" 85}$ Moreover, such differentiation of latent defects and patent defects with respective defect liability periods are standard clauses in numerous infrastructure construction contracts in India, and is, hence, a well-established practice.

Based on the above standard definitions and references to "latent defects" which one finds back in contracts between operatorsupplier (Purchaser-Contractor) in the case of supply of equipment/spares to an operator in the nuclear sector, the following points may be noted:

a. The focus is on remedying the defects when discovered within a specified period; and

b. The situations covered do not envisage a nuclear incident. In other words: the defects need to be remedied, within the pre-agreed time limits of the Defects Liability Period-but repair/replacement is assumed to be accepted to be the appropriate solution between the contracting parties. This would (most often) not be the situation in the event of a nuclear incident which would have triggered the strict liability of the operator to compensate the victims. More specifically still: the right of recourse is not sought as a remedy from the supplier for the repair/replacement of equipment/spares; rather the operator at that stage is seeking compensation for the money paid to the victims.

c. Hence, the reference to the contractual terms of patent and latent defects in Section 17(b) - now, a stand-alone clause independent of whether a right of recourse was inserted as a Clause in the contract between operator-supplier or not-is only relevant to the extent of understanding what a latent defect may

${ }^{85}$ See JoInt BuILding CONTRACTs COMmittee, https://www.jbcc.co.za [https://perma.cc/8WJ6-QWPA]. For a detailed comparison of the JBCC, FIDIC and NEC contracts, see Muhammed Somrey, Jason Gouveia \& Courtney Jones, An Issue for Interpretation, Without Prejudice, in Construction LAW (Aug. 2017), https://withoutprejudice.co.za/free/article/5720/view [https://perma.cc/K7WN-4KAX]. 
mean, but is not intended to attach to it the contractual consequences (repair or replacement)/nor the time-limits specified in the Defect Liability Period, because in principle now Section 17(b) can be relied upon even beyond the time specified contractually in the Defect Liability Period.

d. Moreover, precisely because Section 17(b) is a stand-alone clause, a Judge may appreciate the definition given to "latent defects" in the operatorsupplier contract to understand the intent of the parties but will ultimately be guided by the precedents in his jurisdiction pertaining to "latent defects," which we will study in the section below (see Section VII).

e. It may also be worth noting that the definition of "latent defects" given in the standard operatorsupplier contracts in India - as meaning "a defect, inherently lying within the material or arising out of design deficiency, which do no manifest themselves and/or not reasonably discoverable during the defect liability period"-is in line with the case law pertaining to latent defects.

In summary, as is common practice in most infrastructure contracts, the above clauses clarify that: the Contractor shall design, procure/manufacture, install and complete the Facilities with due care and diligence in accordance with the Contract and with the Purchaser's instructions, and shall remedy any defects in the Facilities occurring in the Defect Liability Period, and remedy latent defects within a further period of $\mathrm{x}$ number of years from the end of the Defect Liability Period. Indeed, at the end of the Defects Liability Period, the Contractor's liability ceases except for latent defects. However, the Contractor's liability for latent defects warranty for the plant and equipment including spares shall be a limited to the agreed number of $x$ years from the end of Defects Liability Period of the respective plant and equipment including spares. 
At times, infrastructure contracts don't always distinguish so clearly whether the Defect Liability Period (also referred to as "defect notification period" or "defect correction period") also covers latent defects and whether the Defects Liability Period would be longer for latent defects or not. ${ }^{86}$ As we have seen in the Table above, however, most standard Purchaser-Contractor contracts in India in the nuclear energy sector do contain clauses specifically addressing latent defects, the liability for latent defects and the defect liability period for latent defects.

In the absence of the CLND Act, any claim pertaining to latent defects would be solely governed by what is contractually agreed between the parties, including the agreed (extended) time limit for latent defects within which a Purchaser can request the Contractor to replace/remedy the latent defect. In other words, after the agreed $\mathrm{x}$ number of years for which the defect liability period for latent defects has been agreed between the parties, the liability of the Contractor/supplier would extinguish and the Purchaser would not be able to claim such replacement/remedy for latent defects.

We may also add here that in the real estate sector in India, insurance companies now also start to issue "Latent Defects Insurance" (LDI) policies to cover the obligation to rectify any defects (structural defects) under the Real Estate (Regulation and Development) Act, 2016 (RERA), if claimed within five years from the date of handing over possession of the unit to allottee by the promoter or the builder. ${ }^{87}$ Such LDI policies taken out by property developers are on the rise globally as a recent insurance trend. ${ }^{88}$ Interestingly, with regards to some of the LDI policy issued in India in the real estate sector, the insurance company appoints an

\footnotetext{
86 Somrey, Gouveia \& Jones, supra note 85.

87 SBI GENERAL InSURANCE, Latent Defects Insurance, https://www.sbigeneral.in/SBIG/sites/default/files/Downloads/Forms_and_Brochures/Broc hures/Prospectus_2.pdf [https://perma.cc/SC7P-Z5GW]. For more information about RERA (and Section 14(3) pertaining to the obligation to rectify defects), see MINISTRY OF Housing and Urban AfFairs, Government of India, Real Estate Regulation and DEVELOPMENT ACT (2016), http://mohua.gov.in/cms/real-estate-regulation-anddevelopment-act-2016.php [https://perma.cc/M5S4-P7JG].

${ }^{88}$ With regard to the real estate market in the UK, see Naresh Dade, Latent Defects Insurance is On the Rise, JLTSPECIALTY.COM (Jan. 25, 2018), https://landlordsinsurance.jltspecialty.com/en-bh/industry/constructioninsurance/construction-insights/latent-defects-insurance-is-on-the-rise [https://perma.cc/J8GM-NMVR].
} 
"Independent Technical Inspection Service Company" to carry out monitoring activities throughout the course of construction on the quality of the building, which could range from sample design checks to witnessing some tests at site (e.g. ultrasonic testing for density of concrete, hardness tests, etc.), and the "Independent Technical Inspection Service Company" will thereafter provide detailed reports and feedback on the quality of the construction as an independent expert party. ${ }^{89}$ As will be discussed below, such practice of independent third party reviewed as part of the INIP mechanism could evolve in the nuclear energy sector in India as well.

B. Distinct Limitation Periods Applicable Between VictimOperator Claims (CLND Act) And Operator-Supplier Claims (Tort Law)

Let's first recall that the CLND Act contains its own limitation period ${ }^{90}$ in Section 18 , within which a victim ${ }^{91}$ needs to file its claim against the operator, which states that the: "right to claim compensation for nuclear damage shall extinguish, if such claim is not made within a period of: a) ten years, in the case of damage to property; b) twenty years, in the case of personal injury to any person, from the date of occurrence of the incident notified under sub-section (1) of Section 3."

Section 18 of the CLND Act also contains a proviso clarifying that where a nuclear damage is caused by a nuclear incident involving nuclear material which, prior to such nuclear incident, had been stolen, lost, jettisoned or abandoned, the said

89 SBI GENERAL INSURANCE, supra note 87 , at 4.

90 The Limitation Act, 1963, in its Section 2(j), distinguishes "period of limitation" from "prescription period" as follows, "period of limitation means the period of the limitation prescribed for any suit, appeal or application by the Schedule, and "prescribed period' means the period of limitation computed in accordance with the provisions of the Act,'http://www.legislative.gov.in/sites/default/files/A1963-36.pdf [https://perma.cc/HS2N-EEBE].

91 As per Section 14 CLND Act, an application for compensation before the Claims Commissioner or the Commission, in respect of nuclear damage may be made by:

(a)A person who has sustained injury; or

(b)The owner of the property to which damage has been caused; or

(c)The legal representative of the deceased; or

(d)Any agent duly authorized by such person or owner of legal representatives. CLND

Rules, supra note 1 . 
period of ten years shall be computed from the date of such incident, but in no case, shall exceed a period of twenty years from the date of such theft, loss, jettison or abandonment.

Moreover, Section 15(2) and Section 31(2) of the CLND Act pertaining to the procedure to be followed before respectively the Nuclear Damage Claims Commissioner/Commission further states that every application for compensation (by the victim against the operator) before the Commission for nuclear damage shall "be made within a period of three years from the date of knowledge of nuclear damage by the person suffering such damage."

Without quoting in full, but for the mere purpose of clarity and illustration, Section 2(g) of the CLND Act defines "nuclear damage" as: (i) loss of life or personal injury (including immediate and long-term health impact) to a person; or (ii) loss of, or damage to, property; or (iii) any economic loss, arising from the loss or damage referred to in (i) or (ii); or (iv) costs of measures of reinstatement of impaired environment caused by a nuclear incident (unless such impairment is insignificant); or (v) loss of income derived from an economic interest in any use or enjoyment of the environment; or (vi) the costs of preventive measures and further loss or damage caused by such measures; or (vii) any other economic loss.

To be clear: Section 18 of the CLND Act prescribes the limitation period in the relationship of victims versus the operator. Only after that will the limitation period need to be calculated within which the operator needs to file its right of recourse claim against the supplier. As we know, Section 17(a) CLND Act covers the situation where the right of recourse is agreed between parties contractually (and in that case the time limit within which such right of recourse can be relied upon will also be determined contractually - see our discussion above in Section VI-A) whereas Section 17(b) must be treated as a stand-alone clause independently of whether a right of recourse provision was inserted in the operatorsupplier contract or not.

As we have discussed (and will further illustrate in the case law discussion below), in the absence of a contract determining the contours of the right of recourse between the operator and the supplier, common tort law will apply. Therefore, the limitation period applicable to torts will determine the limitation period within which the operator can rely on its right of recourse against the 
supplier, after the operator paid the victim(s) as per the Award of the Nuclear Claims Commissioner/commission (and the limitation period governing the victims-operator relationship). As per Part VII of the Schedule to the Limitation Act, 1963, ${ }^{92}$ pertaining to suits relating to tort, the limitation period would be one year for compensation for doing or for omitting to do an act alleged to be in pursuance of any enactment in force, from the date when the act or omission takes place. However, in the context of the right of recourse claim by the operator against the supplier where he can only activate as per the general heading of Section 17 CLND Act "after paying the compensation for nuclear damage in accordance with Section 6," this one year limitation period as per the general Limitation Act will necessarily have to be calculated from the date that the operator paid the compensation for nuclear damage, as his right to claim back (part of) the amount from the supplier by way of right of recourse, will only start once he has met his own obligation to first pay the victims as per the Award - only then can he start exercising his right of recourse against the supplier, not before. ${ }^{93}$

Section 16(1) and Section 32(6) of the CLND Act specify that respectively the Claims Commissioner/Claims Commission after duly giving an opportunity of being heard to the parties, dispose of the application within a period of three (3) months from the date of such receipt of application and make an Award accordingly.

Let's take a purely hypothetical example:

a) A nuclear incident occurred on $1^{\text {st }}$ June 2015 .

b) As per Section 3(1) CLND Act, the AERB notified the nuclear incident on 14 June 2015.

c) The right to claim compensation for damage shall extinguish, if it is not made before:

\footnotetext{
92 Limitation Act 1963 and Schedule (explaining the content of Part VII).

93 Limitation Act 1963, Schedule 72 (Eng.). Schedule 55 relates to compensation for breach of any contract, and the limitation period would be three years, Limitation Act 1963, Schedule 55 (Eng.). For a discussion on UK Limitation Act applicable to latent and patent defects in common law (which is distinct from the present situation), see Christopher Wong, Liability After Take-Over: the English Position, LeXOlOGY (Nov. 5 2009), https://www.lexology.com/library/detail.aspx?g=8646cd6c-13e9-4818-b70d833689607a16 [https://perma.cc/5ZLB-VG2B].
} 
(i) $14^{\text {th }}$ June 2025 , in the case of damage to property;

(ii) $14^{\text {th }}$ June 2035 , in the case of personal injury to any person.

d) A victim files a claim for compensation for nuclear damage to its property on 15 February 2017, before the expiry of the 10 year limitation period and well within the three year knowledge period.

e) The Claims Commissioner issues its Award on $2^{\text {nd }}$ April 2017, within the three month deadline within which the CLND Act mandates him to render its Award.

f) The operator pays the victim within one month from the date of the Award (to avoid paying interest for delayed payment), for example, on $2^{\text {nd }}$ May 2017.

g) After paying the victim on $2^{\text {nd }}$ May 2017, the operator's limitation period of one year to rely on its right of recourse against the supplier will expire on $2^{\text {nd }}$ May 2018.

As pointed out by Saul and Hall Perloff, from a general policy and business perspective, parties need to know at which point their responsibilities end because without such "transactional endpoint" persons (and their insurance companies) would be reluctant to enter into binding agreements for fear that they might never extricate themselves from potential liability ${ }^{94}$ However, with regards to the right of recourse in Section 17(b) CLNDA Act, the time limits contractually specified for the Defect Liability Period, will not impose a time limit on the Section 17(b) claim; in that case only the standard limitation period to file claim for damages under tort law, as per the Limitation Act, 1963, will apply.

94 Saul Perloff \& Hal Perloff, Latent Defects in Government Contracts Law, 27 PuB. CONT. L. 87, 89 (1997). 
We must pinpoint that the general understanding in the legal community so far has been: either the latent defect liability period is addressed in the contract and that contractual arrangement shall govern the legal relationship between the parties, or if the parties were silent on the liability for latent defects, the common law rules will apply. The CLND Act has now created a situation by disconnecting Section 17(b) from the contractual right of recourse situation (Section 17(a)) and treating it as a stand-alone clause, that even if the parties explicitly address and agree on how latent defects need to be addressed, and the defects liability period for latent defects expires, Section 17(b) will still give a separate ground to the operator to claim money back from the supplier for the money it paid to the victim as per the Award of the Claims Commissioner.

The difference, quite subtly but importantly being, that whereas the contractual defect liability period focuses on the liability to replace/remedy the latent defect, in the case of a right of recourse by the operator against the supplier after having paid the victims as per the Award, it no longer holds the supplier liable to replace/remedy the latent defect, but rather to pay back the operator for the (full / portion) of the amount it paid to the victims to the extent of its contribution to the nuclear incident. The operator will need to prove the liability for latent defects of the supplier as per general rules of tort law, as will be discussed below.

Some authors, such as Somrey, Gouveia and Jones, are of the view that - even independent of the context of the CLND Actthe defect notification period only creates the obligation to put the defect right, but does not address liability for the defect in general, beyond the obligation to actually remedy the defect. Therefore, "the common law remedy to claim damages is not extinguished since all that the defect notification period does is limit the timeframe in which the employer has the right to notify and compel the contractor to return to site and make good the defects at the contractor's own expense." ${ }^{\circ 5}$ This would also entail that after the expiry of the defect notification period (whether patent or latent), the purchaser/employer/operator no longer has the legal right to compel the contractor/supplier to make good the defects that were notified within the specified period, but that instead the purchaser/employer/operator would have the right to file a claim for

95 Somrey, Gouveia \& Jones, supra note 85. 
damages against the contractor/supplier based on common law. ${ }^{96}$ As a result, once we move away from the pure contractual claims and the meaning given therein to latent defects and patent defects and their respective defective liability periods, and enter the tort law realm of claims for damages based on negligence, the issue revolves around establishing the three constituent elements of a tort (as discussed above), to know: (1) a legal duty to exercise due care (by the defendant); (2) a breach of the said duty (by the defendant); and (3) consequential damage (suffered by the plaintiff). In other words: once the claim does not relate to the breach of contract per se, but is based on a right of recourse embedded in tort law, the distinction between latent defects and patent defects will fade, ${ }^{97}$ and the focus will be on proving the three constituent elements of a tort of negligence (whether pertaining to latent or patent defects).

\section{Case Law Relating To Latent Defects}

It must be clarified from the outset that in India there is no case law pertaining directly to the meaning of "latent defects" in the nuclear energy sector. That said, there is abundant case law addressing the meaning of "latent defects" in a variety of other contexts. Wherever possible, references will be made to case law in the infrastructure sector or pertaining to mechanical defects, to a large extent because the background in many infrastructure contracts and relationships between a Purchaser of services/material and a Supplier in the infrastructure field will be closely related to the nuclear energy sector.

In Minu B. Mehta v. B.R. Nayan the Supreme Court rejected the appeal by an insurance company which argued that the accident was caused by a latent defect, in this case a mechanical failure, instead of the rash driving of the lorry driver based on lack of evidence. ${ }^{98}$ It further states that the "owner is not liable if the accident is due to a latent defect which is not discoverable by

\footnotetext{
${ }^{96}$ Id.; Yassir Mahmood, Patent Defect Or Latent Defect: Does It Matter?, THOMson Reuters: Prac. L., CONSTRuction Blog, (Jan. 21, 2014), http://constructionblog.practicallaw.com/patent-defect-or-latent-defect-does-it-matter/ [https://perma.cc/BS6M-DN8C].

97 Mahmood, supra note 96.

98 Minu B. Mehta and Another v. Balkrishna Ramchandra Nayan \& Another, (1977) 2 SCC 441 (India).
} 
reasonable care" and further referred to Henderson v. Henry E. Jenkins \& Sons which posited the law on the subject. ${ }^{99}$ In that case, the lorry driver applied the brakes of the lorry on a steep hill but which failed to operate, as result of which the lorry struck and killed a man who was emerging from a parked vehicle. The defence was that the brake failure was due to a "latent defect not discoverable by reasonable care" on the driver's part. Evidence was adduced and it was found that the brake failure was due to a steel pipe bursting caused by corrosion. The corrosion had occurred where it could not be seen except by removing the pipe completely from the vehicle (which had never been done). Expert evidence further showed that it was not a normal precaution to do this if, as was the case, the visible parts of the pipe were not corroded. The corrosion was unusual and unexplained. An expert witness said it must have been due to a chemical reaction of some kind such as exposure to salt from the roads in winter or on journeys near the sea. The House of Lords held that the burden of proof which lay on the defendants to show that they had taken all reasonable care had been discharged in this case. The defect remained undiscoverable despite due care. As the evidence had shown that something unusual had happened to cause this corrosion it was necessary for the defendants to show that they neither knew nor ought to have known of any such unusual occurrence to cause the breakdown. ${ }^{100}$

The above discussion in the Minu B. Mehta case clearly shows that expert evidence pertaining to a particular sector will be taken into account by the courts to understand whether a defendant has met his standard of reasonable care or not. Similarly, in the nuclear energy sector, if an operator were to file suit based on its right of recourse, e.g. claiming that the supplier supplied equipment which contained a latent defect, the supplier will try to prove that it took all measures required from a supplier of his qualifications in the ordinary course of his business in the nuclear sector. Conversely, a supplier may also try to put up a contributory negligence defence and try to establish that it was the Purchaser who (partly) failed in his own duty of reasonable care as an operator. Indeed, in most construction disputes relating to latent defects, the defendant/supplier would try to establish that the defect

\footnotetext{
99 Henderson v. Henry E. Jenkins \& Sons, (1970) AC 282 (India).

100 Balkrishna Ramchandra Nayan \& Another, (1977) 2 SCC 441, 14 (India).
} 
is not a latent defect and that the knowledge of the defect can be inferred given that the plaintiff/operator should have discovered it by, e.g. due diligence of conducting reasonable inspection. Again, this will be a fact-based analysis, with analysis based on which type of inspections a reasonable operator would have undertaken given his expertise and given standard practice in the nuclear energy sector. Quite obviously, with regard to nuclear power plants, the question of whether a defect constituted a latent defect will not be based on a layman's understanding and his means of assessing whether there was a latent defect, but the benchmark will be that of a person possessing superior knowledge and expertise considered reasonable for the nuclear energy sector. In other words: reasonableness and, for instance, what constitutes a reasonable inspection will be sector-specific and based on a factual determination, supported by the view and evidence of experts in the field which both parties (plaintiff/defendant) will submit. ${ }^{101}$

Courts will also take the nature of the sector into account, in terms of whether these are inherently dangerous activities and what the fallout could be in the event of an accident. This will influence the benchmark of reasonableness. For instance, in one of the oldest aviation accident cases in the US, Maynard v. Stinson, the court held the plane manufacturer answerable for taking precautions which would have been commensurate with the damages which would likely result in the absence of such precautions because "the magnitude of possible harm in plane accidents is so serious, it does not seem unreasonable to hold the manufacturer responsible for taking almost all possible known safeguards" and further stated: "Ordinary care in cases where the result of a slip will be slight and unimportant is not sufficient care to fill the requirements of ordinary care where the result of a failure to exercise it will be dangerous or destructive to human life." 102

With regard to contributory negligence of the plaintiff, the Supreme Court explained the legal position clearly in Pramodkumar

\footnotetext{
101 J. Keith Ramsey, Practical Considerations to Recovery for Damages Caused by Latent Construction Defects, LeXology (Sept. 7, 2011), https://www.lexology.com/library/detail.aspx?g=2bd697d3-c7b8-4215-98137cc027821695 [https://perma.cc/9KTG-JD6L].

102 Aircraft Manufacturer's Liability for Defects in Construction and Design, 23 J. AIR L. \& Com. 108, 110-111 (1956); Albert R. Abramson, Defining the Design Defect in Aircraft Products Liability Cases, 45 J. AIR L. \& CoM 167, 168-169 (1979).
} 
Rasikbhai Jhaveri $v$ Karmasey Tak (in the context of a car accident) that the question of contributory negligence arises when there has been some act or omission on the claimant's part, which has materially contributed to the damage caused, and is of such a nature that it may properly be described as "negligence." Negligence ordinarily means breach of a legal duty to care, but when used in the expression "contributory negligence" it does not mean breach of any duty. It only means the failure by a person to use reasonable care for the safety of either himself or his property, so that he becomes blameworthy in part as an "author of his own wrong." Subject to non-requirement of the existence of duty, the question of contributory negligence is to be decided on the same principle on which the question of defendant's negligence is decided. The standard of reasonable man is as relevant in the case of plaintiff's contributory negligence as in the case of defendant's negligence. But the degree of want of care which will constitute contributory negligence, varies with the circumstances and the factual situation of the case. The following observation of the High Court of Australia in Astley vs. Austrust Ltd. is worthy of quoting: "a finding of contributory negligence turns on a factual investigation whether the plaintiff contributed to his or her own loss by failing to take reasonable care of his or her person or property." What is reasonable care depends on the circumstances of the case. In many cases, it may be proper for a plaintiff to rely on the defendant to perform its duty. But there is no absolute rule. The duties and responsibilities of the defendant are a variable factor in determining whether contributory negligence exists and, if so, to what degree. In some cases, the nature of the duty owed may exculpate the plaintiff from a claim of contributory negligence; in other cases, the nature of the duty may reduce the plaintiff's share of responsibility for the damage suffered; and in yet other cases the nature of the duty may not prevent a finding that the plaintiff failed to take reasonable care for the safety of his or her person or property. Contributory negligence focuses on the conduct of the plaintiff. The duty owed by the defendant, although relevant, is one only of many factors that must be weighed in determining whether the plaintiff has so conducted itself that it failed to take reasonable care for the safety of its person or property. ${ }^{103}$

${ }^{103}$ Pramodkumar Rasikbhai Jhaveri v. Karmasey Tak and Ors., (2002) SCC 5436 
Furthermore, it is relevant to keep in mind that many construction contracts have very detailed specifications regarding quality tests and inspection procedures to establish whether e.g. the delivered equipment meets the expected quality standards. If these contractually agreed inspections are duly followed, it will act as affirmative proof that the inspection was performed with reasonable care by the Purchaser/operator and that he could not have discovered the latent defect. ${ }^{104}$ Similarly, Purchaser-Contractor contracts in the nuclear energy field in India, will contain clauses on Quality Assurance, Inspection, Acceptance and Rejection, and in the event of a claim by the operator against the supplier, the operator will wants to establish that these contractual clauses were duly followed. For instance, in order to provide assurance to the Purchaser, the Contractor shall prepare a QA Manual based on the Purchaser's Quality Assurance (QA) Program, which the Purchaser will review and needs to accept. The Quality Management System of the Contractor will include aspects, such as: (i) the procedure for purchase of materials, parts, components, including source inspection, incoming raw material inspection, verification of materials purchased, etc.; (ii) traceability of material used in the production; (iii) control of non-conforming items and system for corrective and preventive actions, including disposal of nonconforming items; (iv) inspection and test procedures for manufacturing activities; (v) control of calibration and testing of inspection, measuring and testing equipment; (vi) system of indication and appraisal of inspection status; (vii) system of quality audits; (viii) system for maintenance of records; etc. The Purchaser/operator will have the right to carry out random quality checks. Moreover, the Purchaser/operator will appoint a Quality Surveillance Engineer/Inspector who will inspect or carry out quality surveillance on suppliers, stores or work under the Contract. Also, the Project Manager appointed by the Purchaser, his duly authorised representative, or even an appointed outside inspection agency acting on behalf of the Purchaser, shall have at all reasonable times access to the Contractor's premises or facilities and shall have the power at all reasonable times to inspect and

(India).

${ }^{104} I d$. 
examine the materials and workmanship during the manufacture stage.

Keep in mind that the discovery of a defect during any of such inspections would qualify the defect not as a latent defect, but as a patent defect. However, the obligation is the same: the defect needs to be remedied, albeit that a different defect liability period would apply, i.e. latent defects attract a longer contractual defect liability period precisely because it is generally accepted that latent defects are more difficult to detect than patent defects. Here too, the Purchaser would then have the contractual right to insist that the Contractor replace / remedy the defect. We must also be mindful of the fact that it is well-established in case law of common law countries (both in terms of general tort law as well as specifically pertaining to construction contracts) that a patent defect is one that is "discoverable" even though it may not have been discovered by a party. Indeed, in one of the often referred to early cases on the subject, Sanderson v. National Coal Board, ${ }^{105}$ the Queen's Bench Division explained that a patent defect is not latent merely because there is none to observe it or because it was not observed. The true question is: was the defect observable by a reasonable person? If the answer is affirmative, it will be treated as a patent defect. Indeed, the Court in this case held that: "the natural meaning of the word 'patent' is objective, not subjective. It means 'observable' not 'observed'. A patent defect must be apparent on inspection, but it is not dependent on the eye of the observer; it can blush unseen." 106 To explain more about the background of the ruling: the case revolved a claim by a miner who had been injured by hooks sticking out from a conveyor belt which badly injured his leg. The person who was in charge of overseeing the conveyor belt submitted that it was dark in the underground area and he could not observe the hooks, the employer taking forward this argument as the defect being latent and not patent. However, the Court clarified that it is not a matter of whether the person in charge actually observed the hooks (defect) sticking out of the conveyor belt, but whether at that point in time the defect had become observable, in an objective manner and could have been observed had they simply used more light in that area. In other words: it is not a defence to merely state

\footnotetext{
105 Sanderson v. National Coal Board, (1961) 2 QB 244-253 (India).

106 Id. at 251.
} 
that a person/ inspector did not observe the defect; but whether the defect could have been observed by a reasonable person/inspector placed in the same circumstances, is the real point. Again, a critical aspect which will be heavily based on the facts of each case and evidence adduced by the parties.

Courts have reiterated the above reasoning of the Sanderson case, and, for instance, held with regard to construction projects that a defect will be patent if it is reasonably discoverable with the help of skilled third party advice (or by analogy: skilled experts directly). ${ }^{107}$

We must further add that in the case of a right of recourse claim based on tort, a Judge will most certainly take into account whether and how the parties followed the Quality Assurance and Inspection steps and procedures as determined in the contract between the parties, but will not be limited by it in the analysis of the alleged tort. This is distinct from, for instance, the US case law pertaining to the Federal Acquisition Regulation (FAR) which provides the US Government with a number of post-acceptance contractual rights, including the revocation of acceptance of latently defective work even after the defect liability period. In those instances, the Government must establish that the latent defect caused the failure of the work to meet contractual requirements. ${ }^{108}$ No such limitations would be applicable when addressing the right of recourse claims by the operator against the supplier based on Section 17(b) CLND Act; and US case pertaining to FAR must be distinguished on that point (although it may remain relevant to assess how latent defects were investigated and which type of evidence was adduced). In the context of FAR-related case law, contactors will often argue that a defect is not latent because it could have been discovered had the Government conducted certain tests or inspections. However, this argument will only prevail if conducting such tests or inspections was reasonable under the circumstances.

107 MAHMOOD, supra note 96; Baxall Securities Ltd and Norbain SDC Ltd v Sheard Walshaw Partnership and others, [2002] EWCA Civ 09, [2002] Lloyd's Rep PN 231 (Eng.).

${ }_{108}$ Patricia A. Meagher \& Scott M. Rennie, Exceptions to Final Acceptance: Latent Defects, Fraud \& Gross Mistakes Amounting to Fraud, Briefing Papers (Mar. 2001), https://www.rjo.com/wp-content/uploads/2017/10/exceptionstofinalacceptance.pdf [https://perma.cc/2MLY-QWDV]; Perloff \& Perloff, supra note 94. 
Here again, what will be considered as "reasonable" will heavily depend on the facts of each particular case. ${ }^{109}$

Similarly, in the context of civil liability pertaining to aviation accidents in the US, courts have held manufacturers/designers accountable only for the "knowledge and skill possessed by an airplane designer in the year in which the plane in dispute was designed. This has the effect of protecting the manufacturer from the admission of hindsight evidence" when assessing "ordinary care." 110 The same would be true for the nuclear energy sector, where courts will take into account the various design years of nuclear power plants and the components supplied to it and the knowledge which a supplier would have (or ought to have) had at the time of supplying components, or designing a power plant, as well as the standard safety standards, procedures and manuals applicable at that time pertaining to the manufacture, assembly or installation, which a reasonable supplier active in the nuclear sector would have had to follow as a minimum.

In Rajkot Municipal Corporation v. M. K. Nakum, the breach of duty by a public authority was addressed. ${ }^{111}$ In this case a man died when a tree in a public street fell on him under normal weather conditions. Ultimately, the public authority was held not to be liable. The Supreme Court reiterated that negligence is failure to use such care that a reasonable, prudent and careful person would use, under similar circumstances. In this case, the Court had to analyse whether the defendant (municipal corporation) breached its duty of care not to create a latent source of physical danger/damage to a third party whom he ought to have reasonable foreseen as likely to be affected thereby. ${ }^{112}$ The Court reviewed a long list of cases pertaining to such falling of tree incidents (whether standing on private or public property), including one case where a tree that had fallen from the property of a landlord was proved to have been due to a disease of the roots, but with no other external indication aboveground that it was affected by the disease. After a detailed examination of the evidence, the Court held that since there was no

\footnotetext{
109 Id. at 4.

110 Aircraft Manufacturer's Liability for Defects in Construction and Design, supra note 102102 , at 111 .

111 Rajkot Municipal Corporation v. Manjulben Jayantilal Nakum and Others, (1997) 9 SCC 552 (India).

112 Id. at 17.
} 
apparent evidence that the tree was affected with a disease, the person (landlord) in question was held to have acted reasonably as any other landlord would have done, as the landlord was not a scientific expert in this field. Similarly, in the case at hand it was held that the municipal corporation had no knowledge and could not have had knowledge that a healthylooking tree would cause an accident in perfectly normal weather conditions and thereby it did not omit to fulfil its duty of care to prevent this accident. If, however, the defendant had become aware of the decayed condition of the tree or had the knowledge that the tree was affected by a disease, but had taken no action to prevent the accident, in that case it would have been actionable. ${ }^{113}$

There is abundant case law in India pertaining to the meaning of latent and patent defects in the context of the sale of goods. And the Sale of Goods Act, 1930 has the notion that there is an implied warranty in the goods delivered that they should be free of latent defects. ${ }^{114}$ For instance, in the case of Sorabji Hormusha Joshi \& Co. v. V.M. Ismail, ${ }^{115}$ the Madras High Court referred to Section 16 of the Sale of Goods Act, 1930 on "implied conditions as to quality or fitness" of goods, to define patent and latent defects. In short, Section 16 states that subject to the provisions of the Sale of Goods Act (and any other law being in force), there is no implied warranty or condition as to the quality or fitness for any particular purpose of goods supplied under a contract of sale, except as follows:

(1) Where the buyer, expressly or by implication, makes known to the seller the particular purpose for which the goods are required, so as to show that the buyer relies on the seller's skill or judgment, and the goods are of a description which it is in the course of the seller's business to supply (whether he is the manufacturer or producer or not), there is an implied condition that the goods shall be reasonably fit for such purpose ... ;

(2) Where goods are bought by description from a seller who deals in goods of that description (whether he is the manufacturer or producer or not), there is an implied condition that the goods shall

\footnotetext{
113 Id. at 58-59.

114 Sale of Goods Act, 1930, INDIA CODE, https://indiacode.nic.in/handle/123456789/2390?view_type=browse\&sam_handle=123456 789/1362 [https://perma.cc/H7J6-BWA9].

115 Sorabji Hormusha Joshi \& Co. v. V.M. Ismail, AIR 1960 Mad. 520 (India).
} 
be of merchantable quality: provided that, if the buyer has examined the goods, there shall be no implied condition as regards defects which such examination ought to have revealed.

The Madras High Court, reflecting on similar principles in most common law countries, ruled that, Section 16 of the Act, "divides all such defects into two kinds, often called patent and latent defects. Patent defects are, those which can be found on examination by a person of ordinary prudence with the exercise of due care and attention. Latent defects are those which cannot be discovered on such examination." Hence, there is an implied condition on the seller's part that the goods are free from latent defects; the condition exists even with regard to patent defects as well, if there has been no examination of the goods by the buyer. ${ }^{116}$ These cases help in defining "latent defects" in the specific context of sale of goods; and as a result many contracts will refer to this standard definition of latent defects as well. This stream of case law is also relevant for those contracts which did not explicitly address the issue of latent defects, whereby the law will apply such an implied clause of goods being free of latent defects. ${ }^{117}$

Similarly, US case law also confirms that a rather standard understanding of "latent defects" is relied upon by courts, and will often be interpreted to mean: "latent defects are generally considered to be hidden or concealed defects which are not discoverable by reasonable and customary inspection ...."118 For instance, in Tricon-Triangle Contractors, a water line which had been installed by a contractor started leaking after one year, where a subsequent inspection revealed the nuts were not properly tightened on the bolds holding the pipe flanges together. Here it was held that the Government could not revoke its acceptance because this situation did not qualify as a latent defect. Indeed, it was held that a "latent defect cannot exist if by reasonable means it would have been detected prior to acceptance." ${ }^{119}$ But there are exceptions to the rule in US case law (pertaining to the Federal Acquisition

\footnotetext{
116 Id. at 28.

117 Danniel E. Murray, Implied Warranty Against Latent Defects: A Historical Comparative Law Study, 21 LA. L. REV. 586, 586-605 (1961).

118 Ramsey, supra note 101. See also Meagher \& Rennie, supra note 108 (in particular, the US case law referred to in footnote 22).

119 Perloff \& Perloff, supra note 94, at 97 (quoting Tricon-Triangle Contractors, ENG BCA No. 5553, 92-1 BCAP 24,664, at 123,084).
} 
Regulation or FAR as discussed above) according to which observable defects are necessarily patent. For instance, in Kaminer Construction Corp. v. United States, ${ }^{120}$ the Court of Claims held with regard to the construction of a crane that although not hidden from sight, it was nevertheless a latent defect because only 8 out of 12,000 -odd bolts were undersized and the size discrepancy was not great, therefore the Government could not reasonably have been expected to discover the mistake. ${ }^{121}$ One must add that the threshold of reasonableness for both the operator and supplier in the nuclear energy sector would be higher compared to mainstream construction projects. Indeed, (although still in the context of the FAR case law in the US), courts will not hesitate to assess whether a more demanding inspection than the one specified in the contract would have been reasonable under the circumstances and would have revealed the presence of the latent defect. As mentioned above, in the context of a Section 17(b) CLND Act right of recourse claim for compensation, Indian courts are bound to also take into account the contractual Quality Assurance, Inspection, Acceptance and Rejection clauses, but will go further and beyond the contractual clauses and assess what was reasonable in the specific circumstances of that case in the nuclear energy sector.

Another difficulty with regard to any latent defect in the goods/services supplied by a supplier which is alleged to have contributed to the nuclear incident, is in the case where there is more than one cause which contributed to the ultimate nuclear incident. Just like with aviation accidents, nuclear accidents may often be the result of a multitude of technical and human failures, and recovery of damages will be limited to the portion of damages that the operator/plaintiff establishes with reasonable accuracy to be the result from these latent defects. ${ }^{122}$ Moreover, in such construction-related disputes, very often the contractor will try to defend the position according to which it is the improper use or a design flaw which is to blame for the failure, rather than any error on the part of the contractor. ${ }^{123}$ An analysis of aviation accidents and nuclear power plant accidents often expose a confluence of

\footnotetext{
${ }^{120}$ Kaminer Construction Corp. v. United States, 488 F.2d. 980 (Ct. Cla. 1973).

121 Perloff \& Perloff, supra note 94, at 98.

122 Meagher \& Rennie, supra note 108, at 5.

123 Perloff \& Perloff, supra note 94, at 104.
} 
multiple factors, possibly from both the operator as well as suppliers, human errors and technical failures. ${ }^{124}$

We may also add here that within companies and industries which focus heavily on safety culture and safety management there is a strong focus on precisely trying to detect latent errors to make their own effective safety management and workplace safety systems more robust. ${ }^{125}$ For instance, within the nuclear energy sector, experiences and lessons learned in terms of failures or best safety practices are being shared at various levels (e.g. between regulatory authorities, operators, nuclear energy agencies, etc.), including relating to latent design deficiencies which "can remain unidentified for a long time after the commissioning of the plant and cause significant problems only after many years of operation." 126

The key take-away from the case law discussion above, is that there is no one-size fits all general standard of reasonable care, but that such tort cases are always based on the facts of each case, taking into account the expertise of the respective parties, and will revolve around understanding how a reasonable person in the same circumstances in the same sector with the same expertise would have acted, and to establish this benchmark specific to each case, courts will heavily rely on the evidence from experts in that particular field. Indeed, this seems to be inherent to the "factintensive nature of latent defects disputes." 127

\section{India NuClear Insurance Pool And Its JoInt Risk MANAGEMENT SYSTEM}

As mentioned, this Note's intent is to focus on the notion of "latent defects" in the situation where the operator decides to

\footnotetext{
124 Giuseppe Contissa \& Giovanni Sartor, Liabilities and Automation in Aviation, SESAR Workshop (2012) 6-8, https://www.sesarju.eu/sites/default/files/SID_2012-36.pdf [https://perma.cc/63XF-RJNX]; Ameye, supra note 6, at 2, 5-6.

125 Justin R.E. Saward \& Neville A. Stanton, Individual Latent Error Detection: Simply Stop, Look and Listen, 101 SAFETY SCI. 305, 305-12 (2018); Justin R.E. Saward \& Neville A. Stanton, Latent Error Detection: A Golden Two Hours for Detection, 59 Applied ERGONOMICS 104, 10413 (2017); M.S. Aini \& A. Fakhru'l-Razi, Latent Errors of Socio-technical Disasters, 51 SAFETY SCIENCE 284, 284-292 (2013).

126 IAEA/NEA, Nuclear Power Plant Operating Experience from the IAEA/NEA International Reporting System for Operating Experience 2012-2014, at 21-23, http://www.oecd-nea.org/nsd/pubs/2018/7448-iaea-nea-irs-2012-2014.pdf [https://perma.cc/H5XU-ZAJU].

127 Perloff \& Perloff, supra note 94, at 91, 93-94.
} 
exercise its right of recourse under Section 17(b) CLND Act against the supplier. Given the unique development under the Indian Nuclear Insurance Pool (INIP) which precisely tries to address the civil liability for nuclear damage claims, including between the operator and the supplier, we must add a word on this specific insurance mechanism as well. ${ }^{128}$

In June, 2015, INIP, the 27th nuclear insurance pool, was formally launched, with the General Insurance Corporation of India (GIC Re), being the Pool Manager, with a total capacity to be achieved of Rs. 1,500 Crores (about USD 237,5 million), corresponding to the capped liability amount resting on the operator as specified in Section 6(2) of the CLND Act. Most interestingly is that INIP was also mandated to cover the risks of the suppliers under Section 17(a) and Section 17(b) of the CLND Act via an insurance policy for suppliers to cover their right of recourse risk. Quite understandably, the right of recourse situation foreseen under Section 17(c) CLND Act pertaining to the intentional act of an individual is not covered. Hence, INIP will issue two types of policies: a) Nuclear Operator's Liability (CLND Act 2010) Insurance policy; and b) Nuclear Supplier's Insurance Policy (Right to Recourse only under CLND Act, 2010).

GIC Re along with 11 other non-life insurers have gathered about $2 / 3$ of the required capacity so far, ${ }^{129}$ and the balance capacity will be contributed by the Government on a tapering basis. ${ }^{130} \mathrm{We}$ must add here that the international insurance market has not committed any capacity or reinsurance support to INIP based on various concerns relating to this unique insurance construct (including relating to risk inspection, pricing, etc.).

The first Operator's Policy was issued to the Nuclear Power Corporation of India Ltd. (NPCIL) on 26 May, 2016; and the Supplier's Policy was unveiled shortly after in August, 2016. However, no such supplier policy has been issued to a supplier yet as on date.

\footnotetext{
128 KINI, INDIA's NUCLEAR TRADE, supra note 2.

129 Consisting of both public sector undertakings and private companies, with the New India Assurance Co. Ltd. being the designated Policy Issuing member company.

130 Question 14 of the Frequently Asked Questions and Answers on Civil Liability for Nuclear Damage Act 2010 and Related Issues ("FAQ") (Feb. 8, 2015), http://www.mea.gov.in/press-

releases.htm?dt1/24766/Frequently_Asked_Questions_and_Answers_on_Civil_Liability_fo r_Nuclear_Damage_Act_2010_and_related_issue [https://perma.cc/7EX9-CXQ̄B].
} 
We may have to insert an intermezzo here, pertaining to the situations where NPCIL assumes the role of supplier, as defined under Rule 24(2)(b) of the CLND Rules, ${ }^{131}$ in contracts where NPCIL is the system designer and technology owner, being responsible for safety designs of such installations. More specifically, this would be the case for the indigenously designed Pressurised Heavy Water Reactors (PHWRs). In other words, in such contracts relating to PHWRs designed by NPCIL, NPCIL will contractually agree to be the supplier for the purpose referred to under the CLND Act and Rules. As a result, in such situations it will not necessarily rely on its right of recourse against the supplier, given that NPCIL itself will be deemed to be the supplier. Here, with NPCL being both the operator and the supplier, NPCIL will not be taking a separate supplier policy under the INIP regime and only an operator policy will be issued.

This is the unique approach taken by NPCIL as on date, although it remains to be seen how long this contractual practice will prevail where NPCIL assumes the role of both operator and supplier for its indigenously designed PHWRs.

The further discussion below builds on all the other situations, not pertaining to the PHWRs designed by NPCIL, and where NPCIL will not assume the role as supplier for the purpose of the right of recourse provision.

Given that INIP would be issuing insurance policies to both the operator as well as the suppliers, it would be subrogated in both the rights of the operator as well as the supplier, if the operator decides to exercise its right of recourse. It must be noted that as much as it is legally mandatory for the operator to take out an insurance policy or other financial security to cover its liability (Section 8 of the CLND Act), no such corresponding obligation rests on the supplier. However, most suppliers may decide to opt for this "joint risk management" approach, with corresponding subrogation by the Pool Manager, rather than having a right of

131 Rule 24(2)(b) CLND Rules contains an explanation of the term "supplier" which "shall include a person who-

(i)Manufactures and supplies, either directly or through an agent, a system, equipment or component or builds a structure on the basis of functional specification; or

(ii)Provides build to print or detailed design specifications to a vendor for manufacturing a system, equipment or component or building a structure and is responsible to the operator for design and quality assurance; or

(iii)Provides quality assurance or design services." CLND Rules, supra note 1. 
recourse litigation fought out in court, based on regular fault-based tort law principles, as discussed above.

This proposed insurance-based approach is based on trying to make the operator and suppliers as "partners managing a risk together." 132 While staying within the four corners of the CLND Act, the approach is certainly not built on a pure insurance logic, given that it can be argued that the same risk would be insured twice. This avoidance of multiple coverages of the same risk, is reminiscent of some of the discussions which took place in the 1950s during the discussions reflected in the Harvard Report, and which precisely underpin some of the unique nuclear law principles, such as legal channelling (or economic channelling in the US) and restricting the right of recourse grounds by the operator against the supplier, in deviation of regular tort law. ${ }^{133}$

We further understand that INIP and its policy holders may also want to devise an alternative dispute resolution mechanism, possibly akin to arbitration with (pre-agreed) expert arbitrators, to avoid lengthy litigation between the operator and the supplier, particularly because if the supplier opts to obtain an INIP Supplier Policy, INIP would be subrogated in the rights of both parties. Quite clearly it will be very important to identify independent experts whom both parties accept. We must flag that for suppliers who would not have opted for an INIP Supplier Policy, their legal right to defend themselves before regular civil courts would remain unfettered.

As we have mentioned above with reference to infrastructure contracts in the real estate sector in India, the issuance of Latent Defects Insurance (LDI) policies are on the rise. In this context they cover the legal obligation of the developers to rectify latent defects up to five years from the date of handing over the possession of the unit, in line with the new RERA legislation. As part of this LDI policy, the insurance companies also appoint an "Independent Technical Inspection Service Company" to carry out monitoring activities throughout the course of construction on the quality of the building, who will thereafter provide detailed reports and feedback on the quality of the construction as an independent expert party. A similar ongoing independent third party technical review

\footnotetext{
132 Id.

133 HARVARD REPORT, supra note 24.
} 
mechanism, (provided that the necessary independent technical expertise can be found), not necessarily binding in itself but as a reliable barometer of "reasonableness," could be envisaged under the INIP mechanism as well. And given the fact-intensive nature of any right of recourse claim from an operator against a supplier, the mechanism could benefit both parties, whether ultimately adjudicated before a regular civil court or an alternative dispute resolution mechanism.

\section{CONCLUSION}

We have highlighted how nuclear law, with its unique characteristics based on the nuclear law principles which are reflected in both the international Vienna and Paris regimes as well as domestic legislations, such as the CLND Act, will be interpreted by Judges as the applicable lex specialis.

Other inherently hazardous industries, or rather sectors where incidents qualify as high-impact, low-probability events, and with possible transboundary effects, such as the aviation and maritime sectors, also have unique legal rules that govern their sector. Moreover, the notion of strict liability is not unique to the nuclear energy sector but can be found back in many jurisdictions with respect to civil liability of industries engaged in inherently hazardous activities. However, the principle of legal channelling of the liability exclusively to the operator, remains a unique characteristic to the nuclear energy sector.

The public policy debate on precisely how much this special nuclear law regime should be allowed to deviate from standard tort law principles can be traced back to discussions which preceded the adoption of the 1960 Paris Convention and the 1963 Vienna Convention. As we have seen, many of the same arguments and diverging views were reflected in the Parliamentary debates prior to the adoption of the CLND Act as well.

As discussed, parties to the respective Paris and Vienna Conventions ultimately agreed that the civil liability ought, from a public policy perspective, be channelled to the operator exclusively and that the operator's right of recourse against the supplier should be limited to two grounds: (1) when the parties agree so contractually; and (2) in the event of where an individual intentionally caused the damage. 
As we have seen, business practice between contracting parties or in government agreements in the nuclear energy field has evolved such over the years that no such right of recourse is typically inserted in operator-supplier agreements.

We have also touched upon the fact that the contractual liability of latent defects is typically included in all operatorsupplier contracts in India, in line with international infrastructure practice, but in such situations the aim is to ensure the supplier remedies the latent defects; whereas a right of recourse claim instituted by the operator would essentially seek to recover monetarily what it was mandated to pay to the victims by an Award of the Nuclear Commissioner/Nuclear Damage Claims Commission.

The CLND Act adopted in 2010 triggered a fresh debate by inserting a stand-alone right of recourse clause, Section 17(b) of the CLND Act, where the nuclear incident has resulted as a consequence of an act of supplier or his employee, which includes supply of equipment or material with patent or latent defects or substandard services. Clearly, Section 17(b) is even more open-ended and not just limited to situations of patent and latent defects in material, equipment or services provided to the operator. Nevertheless, this Note sought to particularly focus on case law pertaining to "latent defects" given its inherent difficulty and evidentiary challenges. Such reliance on general case law pertaining to latent defects is appropriate given that the legal relationship between the operator and the supplier in a right of recourse claim based on Section 17(b) of the CLND Act would be governed by general tort law principles.

It is well-established based in a long line of case laws in common law countries that latent defects are defects not discoverable by reasonable care. However, an analysis of what constitutes "reasonable care" is very fact and context specific and will heavily rely on factual determinations, supported by the view and evidence of experts in the field. Courts will also take the nature of the sector into account, in terms of whether these are inherently dangerous activities and what the fallout could be in the event of an accident. This will influence and heighten the benchmark of reasonableness.

Courts will also take into account the various design years of nuclear power plants and the components supplied to it and the knowledge which a supplier would have (or ought to have) had at 
the time of supplying components, or designing a power plant, as well as the standard safety standards, procedures and manuals applicable at that time pertaining to the manufacture, assembly or installation, which a reasonable supplier active in the nuclear sector would have had to follow as a minimum at that particular time.

The key take-away from the case law analysis is that there is no one-size fits all general standard of reasonable care, but that such tort cases are always based on the facts of each case, taking into account the expertise of the respective parties, and will revolve around understanding how a reasonable person in the same circumstances in the same sector with the same expertise would have acted. To establish this benchmark specific to each case, courts will rely heavily on the evidence from experts in that particular field. Indeed, this seems to be inherent to the "factintensive nature of latent defects disputes." 